\title{
The Online Health Information Needs of Family Physicians: Systematic Review of Qualitative and Quantitative Studies
}

Piet van der Keylen ${ }^{1}$, BSc, MSc, Dr rer biol hum; Johanna Tomandl ${ }^{1}$, BA, MA; Katharina Wollmann ${ }^{2,3}$, BA, MPH; Ralph Möhler ${ }^{4}$, MSCN, Dr rer med; Mario Sofroniou ${ }^{5}$, BSc (Hons), MB BCh (Wales), MRCGP, MMus, DFSRH, Dr; Andy Maun ${ }^{5}$, Prof Dr; Sebastian Voigt-Radloff ${ }^{3}$, MSc, PhD, Dr; Luca Frank ${ }^{1}$, Dr med

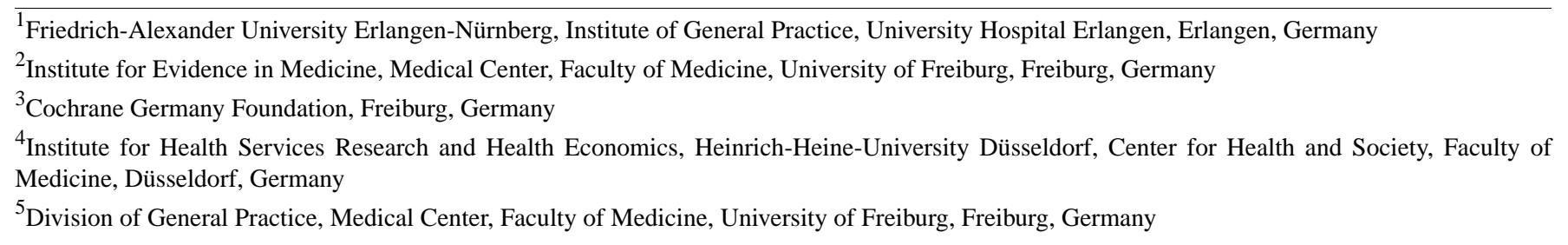

\section{Corresponding Author:}

Piet van der Keylen, BSc, MSc, Dr rer biol hum

Friedrich-Alexander University Erlangen-Nürnberg

Institute of General Practice

University Hospital Erlangen

Universitätsstr 29

Erlangen, 91054

Germany

Phone: 4991318544953

Email: Piet.Keylen@uk-erlangen.de

\section{Abstract}

Background: Digitalization and the increasing availability of online information have changed the way in which information is searched for and retrieved by the public and by health professionals. The technical developments in the last two decades have transformed the methods of information retrieval. Although systematic evidence exists on the general information needs of specialists, and in particular, family physicians (FPs), there have been no recent systematic reviews to specifically address the needs of FPs and any barriers that may exist to accessing online health information.

Objective: This review aims to provide an up-to-date perspective on the needs of FPs in searching, retrieving, and using online information.

Methods: This systematic review of qualitative and quantitative studies searched a multitude of databases spanning the years 2000 to 2020 (search date January 2020). Studies that analyzed the online information needs of FPs, any barriers to the accessibility of information, and their information-seeking behaviors were included. Two researchers independently scrutinized titles and abstracts, analyzing full-text papers for their eligibility, the studies therein, and the data obtained from them.

Results: The initial search yielded 4541 studies for initial title and abstract screening. Of the 144 studies that were found to be eligible for full-text screening, 41 were finally included. A total of 20 themes were developed and summarized into 5 main categories: individual needs of FPs before the search; access needs, including factors that would facilitate or hinder information retrieval; quality needs of the information to hand; utilization needs of the information available; and implication needs for everyday practice.

Conclusions: This review suggests that searching, accessing, and using online information, as well as any pre-existing needs, barriers, or demands, should not be perceived as separate entities but rather be regarded as a sequential process. Apart from accessing information and evaluating its quality, FPs expressed concerns regarding the applicability of this information to their everyday practice and its subsequent relevance to patient care. Future online information resources should cater to the needs of the primary care setting and seek to address the way in which such resources may be adapted to these specific requirements.

(J Med Internet Res 2020;22(12):e18816) doi: 10.2196/18816 


\section{KEYWORDS}

family physicians; general practitioners; primary care; needs; barriers; online information; health information; health resources; internet; information-seeking behaviors; mobile phone

\section{Introduction}

\section{Background}

Digital transformation and the ubiquitous availability of online information resources have diversified the process of obtaining and evaluating information in general. Although information availability has seen a transition from classical sources of information to digital equivalents, it has brought with it new barriers such as technical requirements, paying systems, or the need for paid membership to access certain contents. Following initial work on the information needs of doctors by Covell et al [1], reviews have summarized the needs, information-seeking behaviors, and resources used to answer clinical questions that have arisen from everyday practice [2-12]. One reason for clinicians to conduct an information search is to answer questions arising from their daily practice and patient care [12]. Doctors therefore frequently use the internet for professional purposes [13]. They encounter evermore internet-informed patients, who bring information into the consultation [14] and use the internet as their preferred source of health information $[15,16]$. This inevitably affects the doctor-patient interaction [17] and health-related decision making [18]. The variety and abundance of online medical information may be overwhelming when it comes to critically appraising and evaluating the quality of these resources [19]. Doctors thus face new challenges when it comes to the utilization and adoption emerging through digital transformation in health care. The following questions should be raised: What reasons, facilitators, and barriers exist for doctors during online information searches? How are their information needs and information-seeking behaviors may be affected by digital transformation? Despite the body of available literature, we identified 3 gaps in the literature on the information needs among doctors, leading us to conduct this systematic review:

1. Not family physician (FP)-specific: Half of the systematic reviews examined were not specific to primary care or FP, but on the information needs of doctors in general $[4,7,9,10,12]$, whereas reviews addressing the information needs and information-seeking behaviors of FPs are outdated $[2,3,5,6,8]$. The latest review by Clarke et al [11] in 2013, analyzed the information-seeking behavior of FPs, trainees, nurse practitioners, nurses, and nurse coordinators in a combined review to better understand clinical decision making. As the daily routines of medical specialties differ greatly, so do the respective information needs of doctors [9], which arise from tackling specific clinical tasks in everyday practice [20]. FPs are confronted with diverse clinical questions and therefore may have differing information requirements than other specialist colleagues. These requirements could be met with a multitude of available online tools and software systems developed within the recent decade. To the best of our knowledge, no recent systematic review has exclusively examined the information needs of FPs toward online health information.
2. Out of date: One review from 2011 studied information needs and information-seeking behaviors of hospital-based doctors compared with primary care physicians regarding the access of electronic information [21]. However, technological advancements as well as rapidly changing information delivery systems over the last decade have altered information retrieval in general and specifically in the health care setting.

3. Contradictory evidence: It remains questionable whether the perceived needs of doctors reflect their actual needs [9]. Existing, but not perceived, needs of physicians could remain unexpressed. The analysis of barriers and facilitators before, during, and after the information search itself may give insights into existing but unperceived or unexpressed needs [9].

\section{Objectives}

This systematic review asks "What needs, demands, barriers and facilitators exist for FPs to search for online health information?" We intend to fill these gaps in the literature and aim to do the following:

1. Review studies that analyze the information needs and information-seeking behaviors of FPs in the primary care setting.

2. Focus on online information retrieval by considering the technological advancements in health care and medical information over the last 20 years.

3. Include factors that facilitate or hinder the need for and retrieval of online information in the FP setting.

Therefore, this study intends to summarize the 3 elements of information need, literature searches, and resources as they are interlinked, as suggested by Davies [9].

\section{Methods}

\section{Methodological Approach}

We performed a systematic review.

\section{Search Strategy}

We searched for relevant studies using MEDLINE (via PubMed), Web of Science Core Collection (SCI-Expanded), and Scopus. Furthermore, the reference lists of identified primary papers were screened to identify other potentially relevant citations. The initial search in all databases was performed on May 2, 2018, and updated on January 21, 2020. We formed a search strategy in cooperation with Cochrane Germany and a consulting medical colleague. We started an explorative search term comprising "physician* AND health information AND need." For the specifications of the explorative search strategy, we searched for relevant synonyms and corresponding Medical Subject Headings (MeSH) terms to extend the explorative terms. These were matched with $\mathrm{MeSH}$ On Demand and with MeSH terms in similar papers, retrieved by using the explorative search. We established generated blocks 
for each aspect of the review question, such as the participants involved, the areas of interest, and the setting. Synonyms or similar MeSH terms within each block were combined with the OR operator. The blocks were then combined with the AND operator. We limited our search to the years spanning 2000 to 2020 for the following reasons: global internet access was only widely available from the year 2000 onwards. Subsequently, increased use of the internet could be assumed. This period covers milestone technical developments, such as broadband and mobile internet access, smartphone development and the accompanying hardware and software changes, and social media utilization. Before 2000, only about 5\% [22] of the world population had internet access. Thus, it seems reasonable to limit the timeframe accordingly. The final search terms and search details used are provided in Multimedia Appendix 1.

\section{Inclusion and Exclusion Criteria}

We included original qualitative, quantitative, and mixed methods studies, which assessed the needs of FPs and their requirements for online health information, regardless of the medical indication. These studies included those that assessed these needs explicitly or more implicitly measured requirements, barriers, and demands in asking clinical questions during an FPs' working day or during continuous medical education (CME) programs. If studies addressed a variety of professions or specialties, we only considered those that consisted of at least $50 \%$ FPs in the study population. We included studies retrieved by the search in German and English only, regardless of the impact factor, peer-review process, or publishing process (eg, book, journal, and dissertation).

We excluded the following:

- Reviews, conference proceedings, evidence syntheses, editorials, commentaries, study register entries, protocols, or works that were unobtainable.

- Studies conducted in developing countries that had a very different or underdeveloped health care system, if a reasonable comparison with the primary care systems of the included studies (eg, Germany, the United Kingdom, and France) was not feasible.

- Double publications that only received minor edits or updates to the initial study, by choosing those with the most complete data set.

Furthermore, studies were deemed to be ineligible if:

- The wrong type of information was addressed: As this review aimed at the needs of FPs in obtaining online health information, we excluded:
- Studies that only analyzed health information in exclusively printable (nononline) formats.

- Studies that focused on electronic health records or systems aiming at patient information.

- The wrong population was addressed: patients, general public, or nonmedical health professionals (eg, studies that addressed evaluation or utilization of patient-centered telephone or online counseling, interactive apps, online forums, social media, or patient portals with protected log-ins or personalized patient data).

- Only outcomes not connected to information-seeking behavior or information needs toward online health information were measured (eg, piloting and evaluation of specific knowledge interventions or educational programs for physicians).

\section{Study Selection}

All duplicates were removed automatically using Endnote X9.3.3 (Clarivate) and subsequently by hand. Study selection was performed with Covidence [23], which is specifically designed for Cochrane reviews and frequently used for review management [24,25]. Two researchers (LF and PK) independently screened titles and abstracts and excluded studies that were not eligible. LF and PK then independently screened full-text copies of potentially relevant papers, excluding any studies that were not eligible and documenting the reasons for exclusion. Any disagreements in any phase were resolved through discussion and consensus. Due to the broad themes of independently screened papers, we did not measure inter-rater reliability (kappa) because a quantitative measurement of agreement would not have reflected the qualitative consensus process.

\section{Data Extraction}

Two reviewers developed and piloted a data extraction form independently and manually and obtained the following study characteristics: authors, publication date, title, study type (quantitative, qualitative, or mixed methods), type of data collection (questionnaires, interviews, etc), recruitment of participants (email, hospital, etc), number of FP participants, indication for the health information addressed, the type of health information (online, app, etc), and the outcome variables (needs and requirements). The reviewers resolved any disagreements in the extraction phase through discussion and consensus. An overview of the data extraction phase, including quality appraisal, results analysis, and synthesis, is displayed in Figure 1. 
Figure 1. Methods overview for study selection, quality appraisal, and results synthesis (for details see text). AXIS: appraisal tool for cross-sectional studies; CASP: critical appraisal skills program.

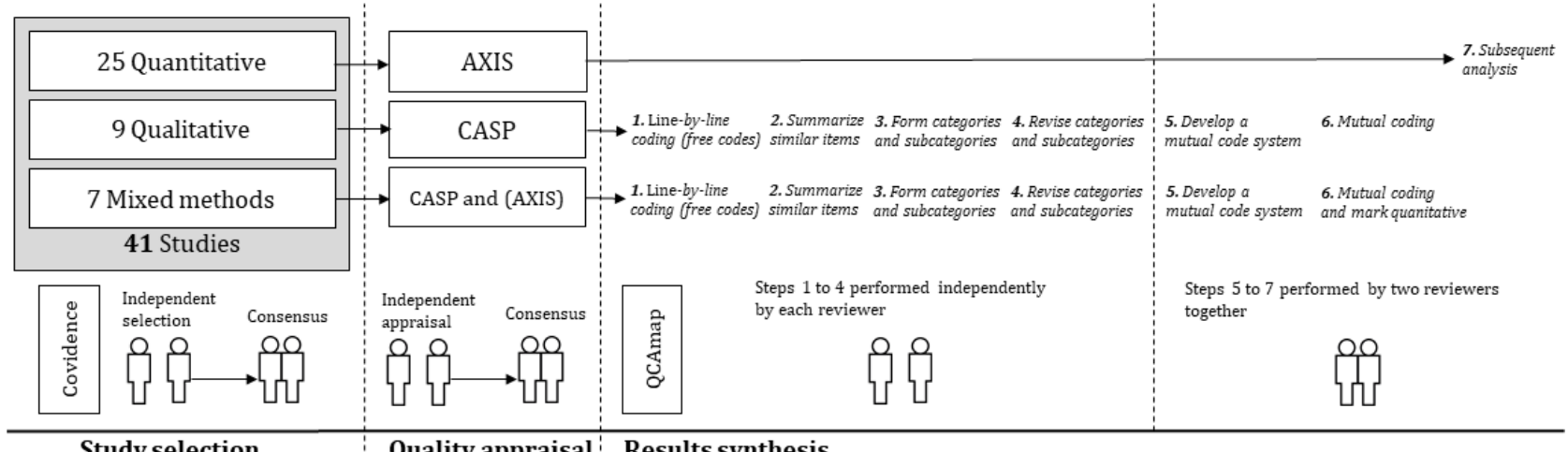

\section{Quality Appraisal of the Studies}

The quality of the studies was assessed by using 2 instruments. For qualitative studies, we applied the critical appraisal skills program (CASP) checklist [26]. For quantitative studies, we applied the appraisal tool for cross-sectional studies (AXIS) tool [27]. For mixed methods studies, we applied the CASP checklist and, if applicable, the AXIS tool. CASP offers distinct and easy-to-use checklists for critically appraising different forms of evidence and studies adapted from the JAMA Users Guide to the Medical Literature [28] and is used in similar reviews [29]. The AXIS tool is a new appraisal tool for cross-sectional studies, currently cited in more than 60 reviews as well as in a recent systematic review assessing the effectiveness of apps [30]. As many of the included quantitative studies had a cross-sectional design, it seemed suitable for this review. AXIS offered no numerical scale to assess quality, but instead aimed to assess the individual characteristics of a study and therefore seemed suitable, as quantitative data were too heterogeneous to perform meta-analyses. Critical appraisal also served as an indicator of possible strengths and weaknesses of the studies and any possible implications for thematic synthesis. All quality aspects were extracted independently by 2 reviewers ( $\mathrm{LF}$ and $\mathrm{PK}$ ) in a separate data sheet and were later combined by discussion and consensus into the tables shown in Multimedia Appendices 2 [31-46] and 3 [21,32,34,36,40,47-70].

\section{Analysis and Synthesis of Results}

A structured analysis of all included studies as well as thematic synthesis was performed based on the method described by Thomas and Harden [71] and according to a systematic review by Möhler and Meyer [72]. All full texts, figures, tables, and supplementary materials of the included studies were uploaded to a qualitative content analysis software (QCAmap), according to Mayring [73]. In studies where mixed populations were addressed, but FPs made up at least $50 \%$ of the study population, we only extracted qualitative and quantitative data if they were represented separately. They were excluded from the study if data regarding FPs were not separately extracted. Data synthesis was performed in 7 stages (Figure 1):

1. The results of the qualitative and mixed methods studies were coded line by line according to the meaning of the content (free codes). The free codes were named as per the description of the item, enabling the reader to identify the way in which an item was defined in the text of the included studies.

2. A superior item name was generated to summarize the descriptions of similar items.

3. Item names were organized into related areas of descriptive themes (main categories and subcategories) by inductive category formation [73].

4. These categories were compared within the studies to analyze similarities or differences, or create new categories, if existing ones were insufficient. Stages 1 to 4 were performed by both reviewers (LF and PK) independently, thereby generating 2 separate code systems.

5. Both reviewers compared and discussed their respective code systems to achieve consensus on a mutual code system.

6. With this mutual code system, the 2 reviewers together again coded all full-text papers line by line, resulting in a more general and objective coding system during text interpretation. In mixed methods studies, where quantitative content showed relevant connections to qualitative content, this content was additionally marked with a quantitative code to later allow linking to both qualitative and quantitative data sets.

7. Purely quantitative studies were subsequently analyzed to support the main categories and subcategories derived from qualitative synthesis in a sequential synthesis design [74] and without conducting meta-analyses.

During the collection of the main categories, this study observed that needs could be expressed directly and explicitly (eg, need for reduced information), or more indirectly (implicitly), by naming distinct barriers (eg, the overabundance of information), perceived lacks (eg, lack of reduced information), and possible facilitators (eg, suggesting less information) during the information search. Where those diverse expressions occurred, they were summarized under the same category to enable the compilation of different aspects of utterance meaning [75]. Furthermore, categories were summarized by acknowledging information search and seeking behavior as a process [9], beginning with a personal need, leading to the access of the information, utilizing it, and the implications of the information used. Inevitably, emerging categories can overlap in certain aspects. 


\section{Results}

\section{Flow Diagram}

After deduplication, the search retrieved 3611 citations. A total of 144 publications were screened in full text, and 103 publications were excluded. We included 41 studies in the synthesis. The study flow is shown in the preferred reporting items for systematic reviews and meta-analyses [76] (PRISMA) diagram (Figure 2).

Figure 2. Flow diagram.

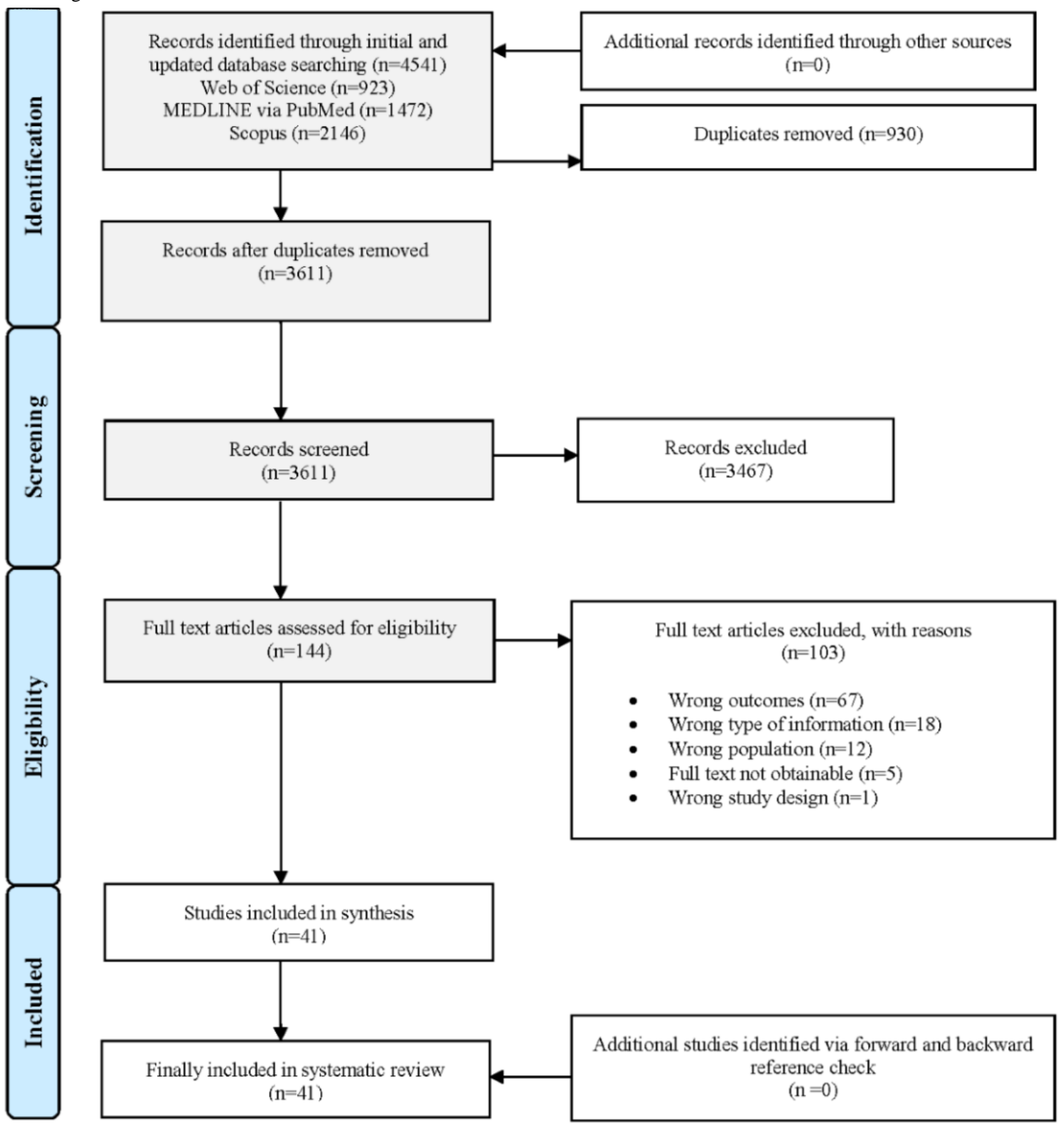

\section{Characteristics of Included Studies}

\section{Type of Studies and Data Collection}

Out of the 41 included studies, 25 were quantitative studies, 9 were qualitative, and 7 were mixed methods studies. Data were collected through a survey $(n=18)$; interview $(n=5)$; questionnaire or logbook (review of medical notes and consultation records; $\mathrm{n}=5$ ); collection of clinical questions by interview or observation $(n=4)$; combined survey, interview, or focus groups $(n=4)$; focus groups alone $(n=3)$; or as a prospective study with electronic data collection $(n=2)$. For a detailed overview of qualitative and mixed methods studies as well as the aims of quantitative studies, their characteristics, recruitment settings, and the outcomes formulated, see Tables 1 and 2. 
Table 1. Characteristics of qualitative and mixed methods studies.

\begin{tabular}{|c|c|c|c|c|c|c|}
\hline $\begin{array}{l}\text { Author (Ref- } \\
\text { erence) }\end{array}$ & Aims & Data collection & Data analysis & Sample size & Main results and themes & $\begin{array}{l}\text { Type of informa- } \\
\text { tion }\end{array}$ \\
\hline $\begin{array}{l}\text { Badran et al } \\
2015 \text { [31] }\end{array}$ & $\begin{array}{l}\text { Explore the viewpoint of } \\
\text { FPs a on advantages and dis- } \\
\text { advantages of educational } \\
\text { email alerts }\end{array}$ & Interview & Thematic analysis & 15 FPs & $\begin{array}{l}\text { Advantages or disadvan- } \\
\text { tages of educational email } \\
\text { alerts; knowledge, attitude, } \\
\text { and behavior toward email }\end{array}$ & $\begin{array}{l}\text { Email or educa- } \\
\text { tional email } \\
\text { alerts }\end{array}$ \\
\hline $\begin{array}{l}\text { Barrett et al } \\
2004[32]\end{array}$ & No clear aim stated & $\begin{array}{l}\text { Survey and inter- } \\
\text { view }\end{array}$ & Descriptive design & $\begin{array}{l}88 \mathrm{GPs}^{\mathrm{b}} \\
\text { (survey); } 15 \\
\text { GPs (inter- } \\
\text { view) }\end{array}$ & $\begin{array}{l}\text { PDA usage by residents; ad- } \\
\text { vantages or disadvantages } \\
\text { of PDA use }\end{array}$ & $\begin{array}{l}\text { Information re- } \\
\text { garding the use } \\
\text { of PDAs }\end{array}$ \\
\hline $\begin{array}{l}\text { Boissin } 2005 \\
{[33]}\end{array}$ & $\begin{array}{l}\text { Consider the use of comput- } \\
\text { ers by GPs, analyze the im- } \\
\text { pact of computerization on } \\
\text { information-seeking behav- } \\
\text { ior }\end{array}$ & Interview & $\mathrm{N} / \mathrm{A}^{\mathrm{c}}$ & 32 GPs & $\begin{array}{l}\text { Computerization; opinions } \\
\text { about new technologies; the } \\
\text { GPs working environment; } \\
\text { information behavior }\end{array}$ & $\begin{array}{l}\text { Internet informa- } \\
\text { tion }\end{array}$ \\
\hline $\begin{array}{l}\text { Bryant } 2004 \\
{[34]}\end{array}$ & $\begin{array}{l}\text { Explore factors that moti- } \\
\text { vate GPs to pursue informa- } \\
\text { tion }\end{array}$ & $\begin{array}{l}\text { Survey interview } \\
\text { and focus group }\end{array}$ & N/A & $\begin{array}{l}19 \text { GPs (in- } \\
\text { terview); } 39 \\
\text { GPs (focus } \\
\text { group) }\end{array}$ & $\begin{array}{l}\text { Information needs and seek- } \\
\text { ing; preferences; attitudes } \\
\text { toward libraries; information } \\
\text { sources used }\end{array}$ & Mixed \\
\hline $\begin{array}{l}\text { Cook et al } \\
2013[35]\end{array}$ & $\begin{array}{l}\text { Understand barriers and en- } \\
\text { abling factors influencing } \\
\text { physician point-of-care } \\
\text { learning and decisions } \\
\text { physicians are facing }\end{array}$ & Focus group & Grounded theory & $50 \mathrm{PCPs}^{\mathrm{d}}$ & $\begin{array}{l}\text { Barriers and enabling factors } \\
\text { of point-of-care learning }\end{array}$ & Mixed \\
\hline $\begin{array}{l}\text { Cullen } 2002 \\
{[36]}\end{array}$ & $\begin{array}{l}\text { Determine the extent of use } \\
\text { of the internet for clinical } \\
\text { information among FPs }\end{array}$ & $\begin{array}{l}\text { Survey and inter- } \\
\text { view }\end{array}$ & N/A & $\begin{array}{l}294 \text { GPs } \\
\text { (survey); } 20 \\
\text { GPs (inter- } \\
\text { view) }\end{array}$ & $\begin{array}{l}\text { Use of internet; information } \\
\text { sources; type of information } \\
\text { sought; search skills; use of } \\
\text { critical evaluation of infor- } \\
\text { mation and impact on deci- } \\
\text { sion }\end{array}$ & $\begin{array}{l}\text { Internet informa- } \\
\text { tion }\end{array}$ \\
\hline $\begin{array}{l}\text { Ely et al } \\
2000 \text { [37] }\end{array}$ & $\begin{array}{l}\text { Develop a taxonomy of } \\
\text { doctors' questions about pa- } \\
\text { tient care }\end{array}$ & $\begin{array}{l}\text { Collection of clini- } \\
\text { cal questions (inter- } \\
\text { view) }\end{array}$ & $\begin{array}{l}\text { Observation and } \\
\text { text analysis }\end{array}$ & 103 FPs & Classify clinical questions & $\begin{array}{l}\text { Clinical ques- } \\
\text { tions }\end{array}$ \\
\hline $\begin{array}{l}\text { Ely et al } \\
2002[38]\end{array}$ & $\begin{array}{l}\text { Describe obstacles encoun- } \\
\text { tered when attempting to } \\
\text { answer doctors' questions } \\
\text { with evidence }\end{array}$ & $\begin{array}{l}\text { Collection of clini- } \\
\text { cal questions (ob- } \\
\text { servation) }\end{array}$ & $\begin{array}{l}\text { Observation and } \\
\text { text analysis }\end{array}$ & 103 FPs & $\begin{array}{l}\text { Obstacles encountered try- } \\
\text { ing to obtain evidence-based } \\
\text { answers to real clinical } \\
\text { questions }\end{array}$ & $\begin{array}{l}\text { Clinical ques- } \\
\text { tions }\end{array}$ \\
\hline $\begin{array}{l}\text { Feightner et } \\
\text { al } 2001[39]\end{array}$ & $\begin{array}{l}\text { Explore FPs' perspectives } \\
\text { on how to provide evidence- } \\
\text { based preventive clinical } \\
\text { practice guidelines to physi- } \\
\text { cians on the internet }\end{array}$ & Focus groups & Thematic analysis & 34 FPs & $\begin{array}{l}\text { Preferences for disseminat- } \\
\text { ing preventative clinical } \\
\text { practice guidelines through } \\
\text { the internet }\end{array}$ & $\begin{array}{l}\text { Internet informa- } \\
\text { tion }\end{array}$ \\
\hline $\begin{array}{l}\text { González- } \\
\text { González et } \\
\text { al } 2007 \text { [40] }\end{array}$ & $\begin{array}{l}\text { Determine information } \\
\text { needs of PCPs and describe } \\
\text { their information-seeking } \\
\text { patterns }\end{array}$ & $\begin{array}{l}\text { Recording consulta- } \\
\text { tions and telephone } \\
\text { interview }\end{array}$ & $\begin{array}{l}\text { Classification of } \\
\text { questions }\end{array}$ & $\begin{array}{l}112 \text { PCPs; } \\
90 \text { PCPs }\end{array}$ & $\begin{array}{l}\text { Number of questions asked, } \\
\text { pursued, and answered; type } \\
\text { and topic of questions; time } \\
\text { spent pursuing answers; in- } \\
\text { formation resources used; } \\
\text { perceived barriers to search }\end{array}$ & Mixed \\
\hline $\begin{array}{l}\text { Heintze et al } \\
2005 \text { [41] }\end{array}$ & $\begin{array}{l}\text { Capture the variety of per- } \\
\text { ceptions and intentions to } \\
\text { act and attitudes of GPs re- } \\
\text { garding their own } \mathrm{CME}^{\mathrm{e}} \\
\text { behavior }\end{array}$ & Interviews & Thematic synthesis & 30 GPs & $\begin{array}{l}\text { Perceptions of CME pro- } \\
\text { grams }\end{array}$ & $\begin{array}{l}\text { Mixed (CME } \\
\text { aspect) }\end{array}$ \\
\hline $\begin{array}{l}\text { Janes et al } \\
2005 \text { [42] }\end{array}$ & $\begin{array}{l}\text { Investigate health profession- } \\
\text { als' attitudes and perceived } \\
\text { barriers to using the internet } \\
\text { for ongoing professional } \\
\text { learning }\end{array}$ & $\begin{array}{l}\text { Cross-sectional } \\
\text { study and question- } \\
\text { naire }\end{array}$ & Inductive approach & $\begin{array}{l}175 \text { GPs } \\
\text { (survey); } 56 \\
\text { GPs (written } \\
\text { response) }\end{array}$ & Barriers to use the internet & $\begin{array}{l}\text { Internet informa- } \\
\text { tion }\end{array}$ \\
\hline
\end{tabular}




\begin{tabular}{|c|c|c|c|c|c|c|}
\hline $\begin{array}{l}\text { Author (Ref- } \\
\text { erence) }\end{array}$ & Aims & Data collection & Data analysis & Sample size & Main results and themes & $\begin{array}{l}\text { Type of informa- } \\
\text { tion }\end{array}$ \\
\hline $\begin{array}{l}\text { Lottridge et } \\
\text { al } 2007 \text { [43] }^{\mathrm{f}}\end{array}$ & $\begin{array}{l}\text { Investigate differences that } \\
\text { impact physicians' needs of } \\
\text { clinical evidence on mobile } \\
\text { devices }\end{array}$ & Interviews & $\begin{array}{l}\text { Verbal protocol } \\
\text { analysis }\end{array}$ & 47 FPs & $\begin{array}{l}\text { Effect of specialty on prefer- } \\
\text { ences toward handheld pre- } \\
\text { sentation of evidence }\end{array}$ & $\begin{array}{l}\text { Mobile informa- } \\
\text { tion }\end{array}$ \\
\hline $\begin{array}{l}\text { Schuers et al } \\
2016 \text { [44] }\end{array}$ & $\begin{array}{l}\text { Explore attitudes and behav- } \\
\text { ior of residents in general } \\
\text { medicine and GPs when } \\
\text { seeking medical information } \\
\text { online }\end{array}$ & Focus groups & $\begin{array}{l}\text { Descriptive analy- } \\
\text { sis }\end{array}$ & 35 GPs & $\begin{array}{l}\text { Research topic in general } \\
\text { medicine; resource selec- } \\
\text { tion; seeking process; re- } \\
\text { search context }\end{array}$ & $\begin{array}{l}\text { Internet informa- } \\
\text { tion }\end{array}$ \\
\hline $\begin{array}{l}\text { Vaucher et } \\
\text { al } 2016 \text { [45] }\end{array}$ & $\begin{array}{l}\text { Assess suggestions of prac- } \\
\text { ticing physicians for possi- } \\
\text { ble improvements of knowl- } \\
\text { edge transition effectiveness } \\
\text { into clinical practice }\end{array}$ & $\begin{array}{l}\text { Interviews; focus } \\
\text { groups; online } \\
\text { questionnaire }\end{array}$ & $\begin{array}{l}\text { Content analysis; } \\
\text { grounded theory }\end{array}$ & $\begin{array}{l}4 \text { GPs (inter- } \\
\text { views); } 25 \\
\text { GPs (focus } \\
\text { group); } 587 \\
\text { GPs (survey) }\end{array}$ & $\begin{array}{l}\text { Barriers in knowledge transi- } \\
\text { tion and suggestions to im- } \\
\text { prove implementation }\end{array}$ & Mixed \\
\hline $\begin{array}{l}\text { Zack et al } \\
2006 \text { [46] }\end{array}$ & $\begin{array}{l}\text { Better understand GPs' infor- } \\
\text { mation needs and prefer- } \\
\text { ences to provide basis for } \\
\text { developing better informa- } \\
\text { tion resources }\end{array}$ & $\begin{array}{l}\text { Questionnaire; in- } \\
\text { terview; review } \\
\text { medical notes }\end{array}$ & Grounded theory & 47 GPs & $\begin{array}{l}\text { Reasons for difficulties and } \\
\text { coping strategies; informa- } \\
\text { tion sources used }\end{array}$ & Mixed \\
\hline
\end{tabular}

${ }^{\mathrm{a}} \mathrm{FP}$ : family physician.

${ }^{\mathrm{b}} \mathrm{GP}$ : general physician.

${ }^{\mathrm{c}}$ N/A: not applicable.

${ }^{\mathrm{d}} \mathrm{PCP}$ : primary care physician or practitioner.

${ }^{\mathrm{e}} \mathrm{CME}$ : continuous medical education.

${ }^{\mathrm{f}}$ In this study, family physicians did not make up at least $50 \%$ of the population. However, the studies compared different groups of doctors and were included in the analysis to evaluate the potential differences between family physicians and other specialties. There was heterogeneity in the studies regarding the term family physician, general practitioner, or primary care practitioner. We decided to use the term of the original study rather than trying to find a common definition of family physicians for different studies. Types of information grouping were performed by medium or source. Due to a lack of one common definition for the information medium or sources among studies, we summarized those studies sharing a comparable or similar definition. However, some studies needed to be grouped by the addressed content rather than the analyzed medium itself. 
Table 2. Characteristics of quantitative studies.

\begin{tabular}{|c|c|c|c|c|c|}
\hline $\begin{array}{l}\text { Author (Ref- } \\
\text { erence) }\end{array}$ & Aims & Data collection & $\begin{array}{l}\text { Recruitment and } \\
\text { sample size }\end{array}$ & Main outcomes & $\begin{array}{l}\text { Type of in- } \\
\text { formation }\end{array}$ \\
\hline $\begin{array}{l}\text { Andrews et } \\
\text { al } 2005 \text { [47] }\end{array}$ & $\begin{array}{l}\text { Assess information-seeking behav- } \\
\text { iors and preferences of clinicians }\end{array}$ & $\begin{array}{l}\text { Cross-sectional sur- } \\
\text { vey }\end{array}$ & Network; PCPs ${ }^{\mathrm{b}}=41$ & $\begin{array}{l}\text { Use of and barriers to information } \\
\text { resources }\end{array}$ & Mixed \\
\hline $\begin{array}{l}\text { Bennett et al } \\
2005 \text { [48] }\end{array}$ & $\begin{array}{l}\text { Assess the way FPs }{ }^{\mathrm{c}} \text { use the internet } \\
\text { to look for clinical information and } \\
\text { how patterns vary from other special- } \\
\text { ists }\end{array}$ & Fax survey & $\begin{array}{l}\text { Fax database; } \\
\text { FPs }=457\end{array}$ & $\begin{array}{l}\text { Usefulness of internet as informa- } \\
\text { tion resource; search pattern com- } \\
\text { pared with other specialties }\end{array}$ & $\begin{array}{l}\text { Internet infor- } \\
\text { mation }\end{array}$ \\
\hline $\begin{array}{l}\text { Bernard et al } \\
2012[49]\end{array}$ & $\begin{array}{l}\text { Describe characteristics of GPs }{ }^{\mathrm{d}} \\
\text { using the internet for clinical infor- } \\
\text { mation search to identify barriers } \\
\text { and facilitators to internet use }\end{array}$ & $\begin{array}{l}\text { Cross-sectional sur- } \\
\text { vey }\end{array}$ & $\begin{array}{l}\text { Online question- } \\
\text { naire; FPs }=721\end{array}$ & $\begin{array}{l}\text { Internet use for clinical information; } \\
\text { obstacles and facilitators for internet } \\
\text { use }\end{array}$ & $\begin{array}{l}\text { Internet infor- } \\
\text { mation }\end{array}$ \\
\hline $\begin{array}{l}\text { Bjerre et al } \\
2013[50]\end{array}$ & $\begin{array}{l}\text { Assess feasibility of using informa- } \\
\text { tion generated in the context of what } \\
\text { could become a "routine" clinical } \\
\text { information source }\end{array}$ & $\begin{array}{l}\text { Collection of clinical } \\
\text { questions (secondary } \\
\text { analysis) }\end{array}$ & $\begin{array}{l}\text { Adjacent study; } \\
\text { PCPs=82 }\end{array}$ & $\begin{array}{l}\text { Description of type and frequency } \\
\text { questions asked (secondary analysis) }\end{array}$ & $\begin{array}{l}\text { Clinical } \\
\text { questions }\end{array}$ \\
\hline $\begin{array}{l}\text { Butzlaff et al } \\
2002[51]\end{array}$ & $\begin{array}{l}\text { Demands of GPs toward } \mathrm{CME}^{\mathrm{e}} \text { me- } \\
\text { dia, the used CME sources, and their } \\
\text { efficacy }\end{array}$ & Survey & Database; FPs $=72$ & $\begin{array}{l}\text { Amount of GPs knowledge acquired } \\
\text { after studies. Requirements of GPs } \\
\text { toward CME. Sources of GPs' } \\
\text { CME. Efficacy of CME. Signifi- } \\
\text { cance of the internet. }\end{array}$ & $\begin{array}{l}\text { CME media } \\
\text { and internet } \\
\text { information }\end{array}$ \\
\hline $\begin{array}{l}\text { Ciarlo et al } \\
2016[52]\end{array}$ & $\begin{array}{l}\text { Identify the specific needs of oncol- } \\
\text { ogists and GPs attending cancer pa- } \\
\text { tients }\end{array}$ & Survey & Database; GPs $=147$ & $\begin{array}{l}\text { Information sources; questions fre- } \\
\text { quently asked; dealing with uncer- } \\
\text { tainty; satisfaction with information; } \\
\text { information seeking and time spent; } \\
\text { information needs for specific topics }\end{array}$ & Mixed \\
\hline $\begin{array}{l}\text { Cogdill et al } \\
2000[53]\end{array}$ & $\begin{array}{l}\text { Investigate information needs and } \\
\text { information seeking in primary care } \\
\text { practices serving as educational sites }\end{array}$ & $\begin{array}{l}\text { Interview with fol- } \\
\text { low-up }\end{array}$ & $\begin{array}{l}\text { University; } \\
\text { PCPs }=15\end{array}$ & $\begin{array}{l}\text { Frequencies and categories of ques- } \\
\text { tions generated during patient en- } \\
\text { counter }\end{array}$ & $\begin{array}{l}\text { Clinical } \\
\text { questions }\end{array}$ \\
\hline $\begin{array}{l}\text { Davies } 2011 \\
{[21]^{\mathrm{f}}}\end{array}$ & $\begin{array}{l}\text { Determine information needs of } \\
\text { physicians }\end{array}$ & Survey & $\begin{array}{l}\text { Professional bodies; } \\
\text { PCPs }=256\end{array}$ & $\begin{array}{l}\text { Information needs. Frequency of } \\
\text { formulated questions. Use of com- } \\
\text { puters. Preference in locating evi- } \\
\text { dence. Barriers in accessing electron- } \\
\text { ic information. }\end{array}$ & $\begin{array}{l}\text { Electronic } \\
\text { information }\end{array}$ \\
\hline $\begin{array}{l}\text { Denny et al } \\
2015 \text { [54] }\end{array}$ & $\begin{array}{l}\text { Investigate the use of e-resources } \\
\text { within the GPs' education and } \\
\text { training sector }\end{array}$ & Survey & $\begin{array}{l}\text { Organizations; } \\
\text { GPs=119 }\end{array}$ & $\begin{array}{l}\text { Personal and professional character- } \\
\text { istics associated with use of e-re- } \\
\text { sources. Preferred sources. Frequen- } \\
\text { cy of use. Factors relevant in selec- } \\
\text { tion and use. }\end{array}$ & E-resources \\
\hline $\begin{array}{l}\text { Dwairy et al } \\
2011 \text { [55] }\end{array}$ & $\begin{array}{l}\text { Explore optimal foraging theory to } \\
\text { understand information-seeking be- } \\
\text { havior of GPs, measure costs, and } \\
\text { benefits of information-seeking de- } \\
\text { cisions }\end{array}$ & $\begin{array}{l}\text { Logbook and ques- } \\
\text { tionnaire }\end{array}$ & $\begin{array}{l}\text { Within region; } \\
\text { GPs }=115\end{array}$ & $\begin{array}{l}\text { Time spent on addressing search for } \\
\text { clinical information; preferred infor- } \\
\text { mation source; success in search }\end{array}$ & Mixed \\
\hline $\begin{array}{l}\text { Ebell et al } \\
2011[56]\end{array}$ & $\begin{array}{l}\text { Identify clinical questions health } \\
\text { care professionals have and explore } \\
\text { whether questions could be used to } \\
\text { drive needs assessment for clinical } \\
\text { education programs }\end{array}$ & $\begin{array}{l}\text { Collection of clinical } \\
\text { questions (observa- } \\
\text { tion and survey) }\end{array}$ & $\begin{array}{l}\text { Personal contact and } \\
\text { academic; } P C P s=25\end{array}$ & $\begin{array}{l}\text { Description of type and frequency } \\
\text { questions asked }\end{array}$ & $\begin{array}{l}\text { Clinical } \\
\text { questions }\end{array}$ \\
\hline $\begin{array}{l}\text { Koller et al } \\
2001[57]\end{array}$ & $\begin{array}{l}\text { Clarify reasons for not consulting } \\
\text { the internet and identify alternative } \\
\text { sources of information for problem } \\
\text { solving during patient care }\end{array}$ & $\begin{array}{l}\text { Cross-sectional sur- } \\
\text { vey }\end{array}$ & $\begin{array}{l}\text { Database; } \\
\text { PCPs }=1103\end{array}$ & $\begin{array}{l}\text { Internet access and use; reasons for } \\
\text { not using }\end{array}$ & $\begin{array}{l}\text { Internet infor- } \\
\text { mation }\end{array}$ \\
\hline $\begin{array}{l}\text { Kortekaas et } \\
\text { al } 2015 \text { [58] }\end{array}$ & $\begin{array}{l}\text { Determine how often and how GP } \\
\text { trainees search for answers to clini- } \\
\text { cal queries encountered in daily } \\
\text { clinical practice }\end{array}$ & $\operatorname{Logs}$ & $\begin{array}{l}\text { University; GP } \\
\text { trainees }=76\end{array}$ & $\begin{array}{l}\text { Number of clinical queries and an- } \\
\text { swers pursued and retrieved; out- } \\
\text { come on decision making; resources } \\
\text { used }\end{array}$ & Mixed \\
\hline
\end{tabular}




\begin{tabular}{|c|c|c|c|c|c|}
\hline $\begin{array}{l}\text { Author (Ref- } \\
\text { erence) }\end{array}$ & Aims & Data collection & $\begin{array}{l}\text { Recruitment and } \\
\text { sample size }{ }^{\mathrm{a}}\end{array}$ & Main outcomes & $\begin{array}{l}\text { Type of in- } \\
\text { formation }\end{array}$ \\
\hline $\begin{array}{l}\text { Kostagiolas } \\
\text { et al } 2015 \\
{[59]}\end{array}$ & $\begin{array}{l}\text { Explore the information-seeking } \\
\text { behavior of GPs and their attitudes } \\
\text { toward participatory medicine }\end{array}$ & Survey & $\begin{array}{l}\text { Organization; } \\
\mathrm{GP}=174\end{array}$ & $\begin{array}{l}\text { Information needs and sources; ob- } \\
\text { stacles when seeking information; } \\
\text { perception of participatory medicine }\end{array}$ & Mixed \\
\hline $\begin{array}{l}\text { Kosteniuk et } \\
\text { al } 2013[60]\end{array}$ & $\begin{array}{l}\text { Determine information resources of } \\
\text { FPs to update general medical } \\
\text { knowledge and make clinical deci- } \\
\text { sions }\end{array}$ & $\begin{array}{l}\text { Cross-sectional sur- } \\
\text { vey }\end{array}$ & Database $; \mathrm{FPs}=331$ & $\begin{array}{l}\text { Information sources used and found } \\
\text { to be most accessible and relevant } \\
\text { to needs }\end{array}$ & Mixed \\
\hline
\end{tabular}

Kritz et al Provide insight on the professional Survey

2013 [61] $^{\mathrm{g}} \quad$ internet use among different subgroups of physicians

Le et al 2016 Assess GPs' information-seeking

[62] behavior, perceived importance of medical information sources and associations with GPs characteristics

MacWalter Determine how GPs use online reet al 2016 sources in support of their continu[63] ing professional development

Magin et al Establish prevalence and associa2015 [64] tions of GP trainees in consultation information seeking

Cross-sectional sur- Organizations; vey

GPs $=1580$

Cross-sectional sur- Via email; GPs $=383$ vey

Cross-sectional survey

Mixed promotion; $\mathrm{GPs}=89$

Use of online resources; time spent on searches; rate of success; barriers mation of finding information; search tools

Frequency of use; perceived impor- Mixed tance; associations between GP characteristics and use and importance

Internet usage and reasons for use; intergroup comparisons

Adjacent study; GP trainees $=654$

In-consultation information seeking Mixed from human or nonhuman source

Internet infor-
Magin et al Establish prevalence and associa2017 [65] tions of GP trainees generation of learning goals

Magrabi et Determine long-term use of an onal 2008 [66] line evidence system in routine clinical practice

Cross-sectional survey

Adjacent study; GP Generation of learning goals trainees $=1124$

$\mathrm{N} / \mathrm{A} ; \mathrm{GPs}=59$

spective study (data collection via computer $\log$ )

Ruf et al Examine GPs' attitudes toward and Survey

2008 [67] use of the internet and online CME

Schwartz et Determine if FP faculty answer their al 2003 [68] questions using online resources and the proportions of answers that influenced patient care

Vollmar et al Gain understanding of PCPs' learn2008 [69] ing media preferences

Prospective study (data collection via computer log)

Survey with follow- Postal; PCPs $=57$ up

Adjacent study; ran- Internet use and importance; frequendom sample GPs $=351$ cy and effectiveness of CME

Internet information (CME aspect)

Practice center; $\mathrm{GPs}=3$

Characteristics of questions generated and answered; search time; resources used; barriers to use mation

Resources used for CME and effec- CME media tiveness; demands toward CME media

Adjacent study; Internet access and utilization; re$\mathrm{PCPs}=264 \quad$ quirements toward CME media

Clinical questions

Online tool

Vollmar et al Gain understanding of GPs' prefer- Survey

2009 [70] ences for different forms of educational media that will meet $\mathrm{CME}$ needs

\footnotetext{
${ }^{\text {a }}$ Sample size describes family physician staff included. If mixed personnel were surveyed or addressed, nonphysicians were excluded from the description and analysis.

${ }^{\mathrm{b}} \mathrm{PCP}$ : primary care physician or practitioner.

${ }^{\mathrm{c}} \mathrm{FP}$ : family physician.

${ }^{\mathrm{d}} \mathrm{GP}$ : general physician.

${ }^{\mathrm{e}} \mathrm{CME}$ : continuous medical education.

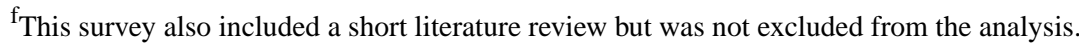

g In these studies, family physicians did not make up at least $50 \%$ of the population. However, the studies compared different groups of doctors and were included in the analysis to evaluate the potential differences between family physicians and other specialties. There was heterogeneity in the studies regarding the term family physician, general practitioner, or primary care practitioner. We decided to use the term of the original study rather than trying to find a common definition of family physicians for different studies. Types of information grouping were performed by medium or source. Due to a lack of one common definition for the information medium or sources among studies, we summarized those studies sharing a comparable or similar definition. However, some studies needed to be grouped by the addressed content rather than the analyzed medium itself.
} 


\section{Type of Information Addressed}

Most studies addressed mixed online information sources $(n=15)$ or internet information sources $(n=12)$. Few studies focused on mobile information sources $(n=2)$. One study focused on online information delivered via email $(n=1)$ or online information delivered via an online tool or app $(n=1)$. Some studies focused on the process of generating clinical questions in practice $(n=6)$ or analyzed CME as an online health information resource $(n=4)$.

\section{Synthesis of Studies}

A total of 20 subcategories emerged from the coding of the included studies and were summarized into the following 5 main categories:

1. Individual needs: Formed to collect FPs' expressed individual personal needs, barriers, or demands toward online information before initiating a search. This category collected diverse statements from FPs when they directly identified a personal need or more indirectly explained the individual barriers met.

2. Access needs: Formed to collect aspects, needs, or barriers expressed by FPs during the access of online information.

3. Quality needs: Formed to collect aspects, needs, or barriers expressed by FPs toward the quality of online information after being accessed.

4. Utilization needs: Formed to collect aspects, needs, or barriers regarding the subsequent utilization of the retrieved information.

5. Implementation needs: Formed to collect aspects, needs, or barriers regarding consequences and effects that emerged due to or after utilization of online information.

Meta-analyses of survey results were not possible due to the heterogeneity of methods used in data collection. See Table 3 for details of the main categories, items, and item descriptions. 
Table 3. Main categories, themes, and theme descriptions.

\begin{tabular}{ll}
\hline $\begin{array}{l}\text { Main category and subcate- Description } \\
\text { gory }\end{array}$ & Supporting survey results \\
\hline
\end{tabular}

\section{Individual needs}

$\mathrm{CME}^{\mathrm{a}}$

There is a need for continuous medical education in practice. There is a need for being kept up-todate $[33-36,39,42,44,45]$.

Digital skill

Prefer analogue

\section{Access needs}

Time

Time to look up or access information is missing. Information access should be quick [21,31,34,35,38-42,44,45].

Simple

Cost

Language

Technical

\section{Quality needs}

Credible
Collaborations among colleagues or with other clinical fields and experts are important [33-36,38,41,42,44-46].

There is a lack of methodological and scientific principles regarding the practice of EBM. Methodological and scientific skills regarding EBM are needed [34-36,38,41,44,45].

Analogue information may be preferred over electronic resources by FPs $[35,39,42,45]$.
Online resources should facilitate easy access to information. Navigational aspects are important for access to information $[32,36,39,42-46]$.

Access to information is expensive. Access to information should be free $[32,41,42,44,45]$.

Foreign language can be a barrier in the information-seeking process [44].

Hardware, software, or technical issues prevent access to information $[32,38,39,42]$.

Information and the institution offering it should be credible, transparent, and trustworthy. Information should be independent from pharmaceutical firms or industry [32,34-36,38,39,41,44-46].
$89.7 \%$ ranked knowledge update as high level of importance as information need or motive [59]; 5-point Likert scale (1-2=low, 4-5=high importance), $\mathrm{N}=174 ; 80.4 \%$ of $\mathrm{FPs}^{\mathrm{b}}$ use the internet for work-related continuing professional development [63]; survey, $\mathrm{N}=383$.

Lack of computer or digital literacy skills ranked low level of importance as an obstacle to obtain information by $70.3 \%$ and $65.9 \%$ of FPs [59]; 5-point Likert scale (1-2=low, 4-5=high importance), $\mathrm{N}=174$.

Colleagues as the preferred aid in clinical decision making among FPs [21]; survey, $\mathrm{N}=256$. Colleagues used as information source by $62.4 \%$ of the FPs in making clinical decisions [60]; survey; $\mathrm{N}=330$. For learning activities, German FPs use quality circles $(75.7 \%)$ and colleagues $(58.5 \%)$ as preferred information source with significant correlation between utilization and efficacy [70]; survey, $\mathrm{N}=264$.

$65.0 \%$ of FPs see websites with evidence-based summaries as the leading facilitating factor to use the internet for information seeking in clinical practice [49]; survey, $\mathrm{N}=721.45 .5 \%$ of FPs see difficulties in quality appraisal as a leading barrier to using the internet for CME [67]; survey, $\mathrm{N}=349$.

Medical textbooks $(66.4 \%)$ or books or printed journals $(86.3 \%)$ used by FPs to make specific clinical decisions regarding patient care $[49,60]$; surveys, $\mathrm{N}=721$ and 330 , respectively.

Lack of time ranked as a leading important obstacle when seeking information [59]; 65.3\% high importance, 5-point Likert scale (1$2=$ low, 4-5=high importance), $\mathrm{N}=174.47 .0 \%$ of FPs ranked lack of time as second most important barrier when searching the internet for clinical information [49]; survey, $N=721$. FPs spent least amount of time in complex queries compared with other specialties [61]; survey, $N=500$. Time to search was ranked as the most frequent barrier to look for information [21]; survey, $\mathrm{N}=256$.

FP registrars named ease of navigation as a factor relevant to use of e-resources [54]; mean 4.32, SD 0.61, 5-point Likert scale (1=not important, $5=$ very important), $\mathrm{N}=119.61 .3 \%$ of FPs ranked navigation difficulties first as physician internet barrier [48]; survey, $\mathrm{N}=457$.

Cost was ranked as the second highest obstacle when seeking information [59]; 59.2\% high importance, 5-point Likert scale (12=low, 4-5=high importance), $\mathrm{N}=174$.

Language barrier was ranked third by $34.1 \%$ of FPs as an obstacle when seeking information in clinical practice [49]; survey, $\mathrm{N}=721$.

Most reported difficulties when using online resources for professional development: $62.7 \%$ slow internet connection; $49.9 \%$ additional software needed; $46.2 \%$ access to website restricted; $42.6 \%$ problems logging into online resource; and $37.3 \%$ internet connection problems other than speed [63]; survey, $\mathrm{N}=383$.

Reliability is the second most favored attribute regarding tools for CME [70]; $89.8 \%$ very important, 3 -point ordinal scale $(0=$ unimportant, $2=$ very important), survey $\mathrm{N}=264$. Pharmaceutical sales representatives are the least used information source by FPs [60]; $4.2 \%$, survey, $\mathrm{N}=330$. 


\begin{tabular}{|c|c|c|}
\hline $\begin{array}{l}\text { Main category and subcate- } \\
\text { gory }\end{array}$ & Description & Supporting survey results \\
\hline Concise & $\begin{array}{l}\text { Overabundance of information can result in an in- } \\
\text { effective search of information. Information should } \\
\text { be preselected and comprehensive to FPs' relevant } \\
\text { topics }[31,34,35,38,39,41,42,44-46] \text {. FPs need short } \\
\text { and concise summaries of information } \\
{[35,38,39,41,43-46] \text {. }}\end{array}$ & $\begin{array}{l}\text { "Too much information to scan" named as leading barrier }(47.7 \%) \\
\text { to internet use for information seeking and identified "evidence- } \\
\text { based summaries" and "selected documents" as leading facilitating } \\
\text { factors for information seeking ( } 65.0 \% \text { and } 54.4 \% \text {, respectively) } \\
\text { [49]; survey, } \mathrm{N}=721 \text {. "Content filters" perceived as an important } \\
\text { tool for information search, identified by } 48.0 \% \text { of FPs [61]; sur- } \\
\text { vey; } \mathrm{N}=89 \text {. }\end{array}$ \\
\hline Up-to-date & $\begin{array}{l}\text { Information should be recent and up-to-date } \\
{[35,38,39,42,45,46] \text {. }}\end{array}$ & $\begin{array}{l}\text { "Creation date listed" was identified as an important factor relevant } \\
\text { to GPs }{ }^{\text {d }} \text { use of e-resources [54]; mean } 4.22 \text {, SD } 0.72,5 \text {-point } \\
\text { Likert scale ( } 1=\text { not important, } 5=\text { very important) survey, } \mathrm{N}=119 .\end{array}$ \\
\hline Specific & $\begin{array}{l}\text { There is a need for specific and in-depth informa- } \\
\text { tion among FPs that is highly variable and depen- } \\
\text { dent on the situation (eg, rare diseases and pediatric } \\
\text { doses) }[32,34-36,38,39,41,44,46] \text {. }\end{array}$ & $\begin{array}{l}66.7 \% \text { of FPs search for specific patient information, } 44.0 \% \text { of } \\
\text { FPs identified the lack of availability of specific information as a } \\
\text { barrier to using the internet [ } 48] \text {; survey, } N=457 \text {. }\end{array}$ \\
\hline \multicolumn{3}{|l|}{ Utilization needs } \\
\hline Usability & $\begin{array}{l}\text { FPs identify easy navigation and organized content } \\
\text { as important for the daily usability of an electronic } \\
\text { resource }[32,35,38,39,43,46] \text {. }\end{array}$ & $\underline{\mathrm{e}}^{\mathrm{e}}$ \\
\hline Science-practice gap & $\begin{array}{l}\text { FPs note an existing gap between scientific litera- } \\
\text { ture and the questions arising from daily practice } \\
{[38,45] \text {. }}\end{array}$ & - \\
\hline $\begin{array}{l}\text { Doctor-patient-relation- } \\
\text { ship }\end{array}$ & $\begin{array}{l}\text { FPs see implications for the doctor-patient relation- } \\
\text { ship, when information search is done during the } \\
\text { patient encounter }[33,35,44] \text {. }\end{array}$ & $\begin{array}{l}71.0 \% \text { of FPs name "disturbance of doctor-patient-communication" } \\
\text { as a leading reason for not using the internet [57]; survey, } N=1103 \text {. }\end{array}$ \\
\hline \multicolumn{3}{|l|}{ Implication needs } \\
\hline Patient education & $\begin{array}{l}\text { Information should be useful for patient education } \\
{[32,34-36,39,43,44,46] \text {. }}\end{array}$ & $\begin{array}{l}93.5 \% \text { of FPs use the internet for obtaining information to give to } \\
\text { a patient [63]; survey, } N=383 \text {. }\end{array}$ \\
\hline Justification of practice & $\begin{array}{l}\text { FPs search for information to justify practice or } \\
\text { clinical decision }[34-36,39,41,44,46] \text {. }\end{array}$ & $\begin{array}{l}\text { Improvement of clinical decision making and confirmation of de- } \\
\text { cision are among the most frequently named impacts of information } \\
\text { search among FP trainees [58]; } 25.8 \% \text { and } 22.7 \% \text { of clinical queries } \\
\text { in daily practice; survey; } \mathrm{N}=76 \text {. }\end{array}$ \\
\hline
\end{tabular}

${ }^{\mathrm{a}} \mathrm{CME}$ : continuous medical education.

${ }^{\mathrm{b}} \mathrm{FP}$ : family physician.

${ }^{\mathrm{c}}$ EBM: evidence-based medicine.

${ }^{\mathrm{d}} \mathrm{GP}$ : general physician.

${ }^{\mathrm{e}}$ No substantiating quantitative results are displayed.

\section{Individual Needs}

\section{CME}

FPs identified a need for CME in everyday practice $[33-36,39,42,44,45]$ but did not rank the internet as the most preferred source $[36,49]$ for obtaining CME-related information. Although the work-related utilization of the internet for CME is quite high [63], FPs appear to prefer personal medical education such as colleagues and quality circles for updating their knowledge $[51,67,70]$.

\section{Digital Skill}

FPs mentioned a lack of digital, computer, or internet skills as a potential barrier in obtaining online health information $[31,33,36,39,42,45]$. However, the lack of digital or technical skills was not mentioned as a leading obstacle to obtaining online information $[48,49,57,59,67]$. A cross-sectional survey made more precise distinctions in mentioning digital or technical difficulties when using online resources, displaying the variety of digital or technical barriers that can occur when using new technologies (eg, log-in problems and need for additional software) [63]. 


\section{Collaboration}

FPs expressed the need for collaborations with colleagues or experts throughout different disciplines and institutions (practice, hospital, and universities) when seeking information [33-36,38,41,42,44-46]. Quantitative data from surveys support the utilization of colleagues and experts as an important information resource for FPs [21,51,52,55,57-60,62,69,70]. Colleagues were the resource with the highest success rate when obtaining information among FPs, being more efficient than search engines or websites [55]. Young FP registrars named face-to-face contact with educators or colleagues as the second most preferred resource after using e-resources [54].

\section{Evidence-Based Medicine Skill}

FPs realized a lack of various skills and competences relating to methods and principles of practicing evidence-based medicine (EBM; eg, literature search and critical appraisal) [34-36,38,41,44,45]. Surveys mentioned the difficulty in obtaining quality appraisals as a hindrance to their use of the internet for CME [67] and identified websites with evidence-based summaries as facilitators of their use of the internet for information seeking in clinical practice [49].

\section{Prefer Analogue}

In a few qualitative studies, analogue sources of information were preferred by some FPs over electronic resources $[35,39,42,45]$. Quantitative studies show varying and inconclusive results concerning the FPs' most preferred sources of information [21,47,51,52,55,58-60,62,67,69,70].

\section{Access Needs}

\section{Time}

Lack of time was frequently referred to as a barrier to accessing information. Quick access to information was demanded by FPs in both qualitative studies and surveys [21,31,34,35,38-42,44,45,49,51,57,59,69,70]. FPs were reported as devoting the least amount of time to complex queries, and they are more likely to perceive a lack of time than other specialists [61]. FPs spent 18 min on average on their searches for clinical information [55]. FPs refer to the lack of time as a leading barrier to obtaining information from the internet $[49,57,59]$. FPs also ranked the attribute fast as a leading criterion for the efficient utilization of information $[51,69,70]$.

\section{Simple}

FPs mentioned easy access as an important requirement in the process of seeking and obtaining information. Emphasis was laid on simple technological aspects or technological tools that enhanced information access [32,36,39,42-46]. Surveys supported the fact that complex technological procedures appear to be a hindrance to the access of online information $[49,63,67]$. User friendliness was mentioned as an important requirement in obtaining electronic information $[51,69,70]$. Another aspect was the identification of navigation difficulties as a barrier to obtaining information from the internet [48] as well as mentioning the ease of navigation as a factor that was highly relevant to FPs when using e-resources [54].

\section{Cost}

FPs named costs as a barrier to accessing information. On the one hand, they expressed the need for free access to information, yet on the other hand, they mentioned costs of hardware and software as a hindrance to obtaining information $[32,41,42,44,45]$. Surveys supported cost and cost-effectiveness as a factor for FPs when using CME [51,62,67,69,70], although no obvious conclusion was drawn from the importance of this factor as a barrier to accessing information in general [49,59].

\section{Language}

Qualitative studies rarely mentioned languages as an obstacle for obtaining information [44]. However, surveys identified foreign languages as a possible barrier in the process of seeking information [49,59]. For German FPs, language is of medium importance when using the internet $[67,69,70]$.

\section{Technical}

The technical aspects identified as preventing the access of information or displaying a barrier to the process of seeking information were named in several studies covering a wide variety of technical, hardware and software, or internet-related problems [32,38,39,42]. A quantitative survey among Scottish FPs identified several distinct issues, such as a slow connection or incompatible software, when accessing information for CME [63].

\section{Quality Needs}

\section{Credible}

FPs' needs regarding the quality of information, trustworthiness, credibility, and transparency of information and the institution generating this information were frequently named in qualitative studies [34-36,38,39,44-46]. Transparency and credibility were often linked to the need for information to be independent from the pharmaceutical industry [32,38,41,44,45]. Quantitative studies supported the need for trustworthy, credible, and transparent information among FPs $[48,51,57,60,63,67,69,70]$.

\section{Concise}

FPs cited an overabundance of information as a barrier to the process of searching for specific or relevant information. The internet and other electronic information resources were perceived as containing an untamed information jungle, hindering the effectiveness of researching FP-relevant information [31,34,35,38,39,41,42,44-46]. This result was supported by several surveys that addressed the need for concise information or identified too much or confusing information as an access barrier $[49,51,54,57,59,61,67,69,70]$. Another aspect identified by several qualitative studies was the FPs' need for short and concise summaries of information [35,38,39,41,43-46].

\section{Up-to-Date}

Another need identified by FPs was the currency of information available [35,38,39,42,45,46], which was chiefly cited by qualitative analyses rather than quantitative studies [54,67].

\section{Specific}

FPs seemed to show differing needs for specific information depending on the particular clinical question at hand and the 
individual patient situation. These needs could cover anything from detailed pediatric drug dosing to diagnostic criteria for rare diseases, but could not be narrowed down to any specific or homogenous topic [32,34-36,38,39,41,44,46]. Therefore, quantitative data were too heterogeneous to present a distinct pattern of those specific needs emerging from surveys. However, a survey listed the unavailability of specific information as a barrier for FPs [48]. It was not an aim of this review to analyze the distinct medical information FPs were searching for, but some of the included studies identified these topics or developed or used the taxonomy of clinically generated questions by FPs $[37,40,50,56,64,65,68]$. This supported the highly heterogeneous field of clinical questions that could arise from the FPs' daily routine. Cook et al [35] noted that the complexity of clinical questions was an important aspect to consider among FPs.

\section{Utilization Needs}

\section{Usability}

The most prominent aspect retrieved was the need for easy navigation and an organized display of structured content $[32,35,38,39,43,46]$. Minor aspects retrieved from some studies also mentioned the need for short and summarized information $[35,39]$ and aspects regarding mobile or tablet resources such as physical size, screen requirements, or applications used $[32,43,45]$. Quantitative evidence identifying needs as suitable for daily practice utilization was sparse [70].

\section{Science-Practice Gap}

Few qualitative studies mentioned that scientific literature failed to address and reflect on the relevant problems emerging from daily practice, omitting the connection of academic centers to daily practice $[38,45]$. None of the included surveys directly measured this aspect. Few surveys report that FPs perceived a lack of specific information [48] or the low relevance to clinical practice [49] as a barrier to searching for information on the internet.

\section{Doctor-Patient Relationship}

Qualitative studies suggested considering the setting of the FP encounter with the patient, and possible positive and negative implications on the doctor-patient relationship, as a consideration when information searches were conducted during the encounter $[33,35,44]$. One focus group study, in particular, named the complexity of questions that arose in general practice as a barrier to searching for information [35]. An older survey of Swiss doctors identified the interruption of doctor-patient communication as a reason for not using the internet [57].

\section{Implication Needs}

\section{Relevance for Daily Practice}

One important implication for the FPs' everyday practice was a reported lack of usefulness and relevance of electronic resources in the daily clinical routine. FPs noted that information should be applicable to their specific daily situations, rather than general guidelines and recommendations $[32,34,35,38,41,42,44-46]$. Surveys supported the need for information relevance to daily practice $[51,67,69,70]$ or identified low relevance as a barrier to information seeking [49].
Furthermore, surveys reported the need for information to make improved clinical decisions $[58,63]$.

\section{Patient Education}

An important viewpoint of many FPs was the usefulness of retrieved information for patient education or the need for information supporting the patients' involvement in the process of explanation, identified by a number of qualitative studies $[32,34-36,39,43,44,46]$. A survey of Scottish FPs reported that over $90 \%$ of them used the internet to obtain information for the patient [63] or advise patients on internet health resources [47].

\section{Justification of Practice}

Qualitative studies also showed that general physicians (GPs) searched and used information in everyday practice to reaffirm preexisting knowledge or to justify their clinical decisions [34-36,39,41,44,46]. The search strategies of FP trainees also demonstrated the impact on clinical decision making or the confirmation of a diagnosis [58]. Surveys that developed or relied on the taxonomy arising from FPs' daily practice also supported this finding. The most common question types could be classified according to the categories diagnosis and treatment $[37,40,50,56,64,65,68]$. Surveys also show that the topics diagnosis and treatment were important information-seeking motives or information needs among FPs $[52,53,59]$.

\section{Discussion}

\section{Principal Findings}

This study presented 5 main aspects of FPs' needs toward online health information:

1. Several individual needs exist for FPs before online information is accessed, such as the need for digital and EBM skills, preference for analogue information or a desire for CME, and the need for interspecialist collaborations.

2. Needs that are connected with the access of online information, such as simple access, technical barriers, a good cost-benefit ratio, or suitable languages.

3. Needs that address aspects of quality itself, for instance, credible and recent information. The most interesting aspects of quality revealed a converse need for concise information, on the one hand, as well as the need for specific in-depth information, on the other hand.

4. Needs that are concerned with the feasible utilization of obtained information, such as the suitability of information to the distinct and unique situations in family practice.

5. Needs that reflect the subsequent implications of using information that is tailored to FP practice, clinical judgment and decision making, and patient education as well as providing additional value to the FPs' future practice.

\section{Comparison With Prior Work}

The impact of the internet on the information needs of primary care was reviewed in 1999 and identified FPs' need to manage information overload as well as the need for specific and simple information [5]. This study confirms these findings within the quality needs category and thus confirms prior work as still valid. Rural health professionals have information needs directly 
relating to patient care and therapy, and they cited a lack of time or technological literacy as barriers to obtaining information [6]. Our study supports the relevance of patient-related needs mainly in the utilization and implication needs category. It also confirms time and technological aspects in the access needs category.

Dawes and Sampson [7] noted heterogeneous information-seeking behavior among doctors in 2003 and asked for careful planning in delivering useful, relevant, and fast information to physicians, supported by our findings within the main categories of utilization and implication needs. A noteworthy review from 2006 identified the information-seeking obstacles to primary care physicians in the context of established EBM processes [8]: (1) acknowledging an information gap, (2) formulating a question, (3) seeking relevant information, (4) formulating an answer, and (5) applying the answer to patient care. Although our review is able to confirm most of the barriers reported by Coumo and Meijman [8], it intends to present an adapted classification of the steps necessary for FPs to obtain such information.

The FPs' information needs cannot be completely met by only providing high-quality information through newly tailored online sources. New content, new technologies, or new systems must address seeking competencies, strategies of utilization, and the implications generated in family practice, as our results revealed. The internet's role in needs, the information-seeking patterns, and the sources utilized was partly reviewed by Davies [9]. In agreement with some of our subcategories, prominent barriers identified in information searches were lack of time, lack of information technology skills, and lack of search skills, although needs were often related to diagnosis and therapy. Physicians' information needs are often related to diagnosis, therapy, and patient care, as confirmed by literature reviews from 2010 and 2013 [10,11]. The most recent systematic review in this field of work was conducted by Del Fiol et al [12] in 2014, confirming that clinicians raise questions about patient care. Although our study confirms the findings of these more recent reviews, none of them have been exclusively focused on FPs. Therefore, a substantiating comparison remains complex.

\section{What Is New and Where to Go From Here?}

Despite confirming prior work, this study seeks to highlight possible future work emerging from the results presented. The main categories and subcategories indicate that needs toward online information by FPs seem to be closely associated with CME and EBM. Evidence suggests that EBM interventions improve short-term knowledge, but there is little evidence of a change in long-term knowledge, attitudes, or clinical practice [77]. Despite technological advancements, half of the clinical questions still seem to be unanswered at the point of care [12]. No study has directly measured the effects of these interventions on patients' outcomes or FPs' behavior [8]. The inability to search for the literature and critically appraise the content—both inevitable steps of EBM [78]—were identified as barriers to obtaining information in the first place by this study. We suggest that future work should focus on these intermingling aspects of information need, CME, EBM, and daily routine in the primary care setting. It should not abandon the implications and effects on FPs' behavior or patient outcomes that occur after an information search or when a question is not pursued.

Searching for and critically appraising primary literature in a short amount of time remains a major obstacle in primary care, urging FPs to express needs for concise secondary, credible, free, and simple information that also provides valuable and specific medical information. This converse need for short and concise, but also in-depth, information for an FP, in our opinion, has neither been met by new online information platforms nor by science contributing to the information translation with relevant research into the FPs' daily practice. An FP's need for information rarely starts with a scientific definition of an illness or an update on epidemiology, but with a specific question on individual patients and with direct impact on the situation presented during the consultation. The vast amount of information available across multiple platforms and sources emerges as an obstacle to both initiating and pursuing a clinical question in the FPs' daily practice and consultation. Lack of time remains a major obstacle to information retrieval among FPs, despite the abundance of online information. This emphasizes the fact that online information has not yet fully evolved to satisfy the needs of FPs, explaining that FPs may still prefer colleagues and analogue information in many situations over digital solutions, as it is free, delivered by specialist colleagues, fast, simple, and concise.

\section{Methodological Strengths and Limitations}

To our knowledge, this is the first systematic review that analyses the available qualitative and quantitative evidence focused solely on FPs using online health information. As our search was not limited to a specific study design, we feel it is unlikely, but not impossible, that further relevant publications are available. However, the heterogeneity among countries and their unique health care systems made it challenging to find a common term for family physician, family practitioner, general practitioner, and primary care physician among the studies included. Both the differences in health care and educational systems can result in a heterogeneous study population of family physicians. As this study excluded works from countries with a completely different primary care or health care system or far less developed technological infrastructure than the majority of those in the included studies, this review may display a bias in this aspect of selection.

There is no established methodological approach for synthesizing both qualitative and quantitative data [79], and a variety of methods seems plausible [74]. We, therefore, used specific steps for quality appraisal and synthesis of the studies by following the thematic synthesis by Thomas and Harden [71], referring to the study by Möhler and Meyer [72], and applying the well-established (eg, [28-30]) critical appraisal tools CASP [26] and AXIS [27]. Despite independent review from 2 scientists, the critical appraisal and the reported items cannot cover all aspects of the heterogeneous body of evidence. We neither wanted to unduly appraise nor indecently criticize the studies' quality or the authors' contribution to the scientific community. The final critical appraisal must remain with the scientist using the included original study. According to Hong et al [74], when addressing one overall review question, as is 
the case with this review, a sequential study synthesis design is applicable. Despite presenting qualitative and quantitative results parallel to our results, we first synthesized qualitative themes and then collected evidence from quantitative studies to support and enrich these developed themes.

We tried to minimize an aspect we named technological bias by limiting studies from the years spanning 2000 to 2020 . Through the chosen search terms as well as the established exclusion criteria, we sought to ensure that only studies regarding electronic information were included, when the internet and computers were broadly available in most countries. Still, the technical developments of the last 20 years have been expeditious and have resulted in a rapidly developing infrastructure, hardware, and software environment. We noticed the resulting variety of electronic information, ranging from CD-ROM to very recent online databases. Therefore, a small technological bias remains, especially due to older studies that analyzed technological information systems and corresponding seeking behaviors, which are generally no longer used or even obsolete in 2020 (eg, CD-ROM and Palm OS).

\section{Conclusions: FPs' View}

Although technology and infrastructure, methods, and sources of information retrieval have changed, the needs and barriers of FPs to information seeking and retrieval have not. The question arises, why do technological advancements not succeed in fulfilling the information needs of FPs?

We propose the following two main answers to this question:

1. Human sources of information, such as colleagues, play an important role. FPs are the center of an afferent information flow, as they receive health information from hospitals and other specialists. The FP provides primary care for patients presenting with a variety of illnesses and questions. There is a tension field for the FPs as information givers with an efferent information flow toward the patient. FPs need to develop coping strategies to tackle the demands met in this center of bidirectional information flow by seeking CME and EBM, both instruments to improve knowledge and information retrieval.

2. FPs acknowledge their need for digital skills to search and find the information needed in the online information jungle. It is interesting to note that the methods used for providing this information have come to signify the transition from the analogue to the digital era, although the way of presenting this information for the FPs' daily work has not yet kept up with this transition.

This review aims to contribute to a (1) FP-specific and (2) an updated systematic body of research that also sought to analyze (3) the influencing factors affecting needs and requirements for online information in primary care. This study concludes that FPs show specific needs for online information due to their daily routine and broad working environment. Future information resources, whether online or analogue, must address the needs emerging from the primary care setting as well as rethink the way in which information is adapted to the needs of the digital age. This requires not only the development and implementation of new information systems but also the evaluation of their effects on both physicians and patients. Finally, science should also rethink the way online medical information is disseminated, adapted, and translated into daily practice.

\section{Acknowledgments}

The authors thank Kathrin Schnitzius for helping to prepare the manuscript and for revising the referenced literature. The authors thank Andrea C Schöpf for the initial help with finding a fitting methodological approach and the critical appraisal items. The authors thank Angelina Kloz for critically revising the main categories, subsequent items, and item descriptions. The authors want to thank all authors of the included original studies for their work that made this review possible. This review is part of the General practitioner And Patient communication trial (DRKS00014279, German Clinical Trial Register). The trial is funded by Innovationsausschuss of the Gemeinsamer Bundesausschuss Grant no: 01NVF17010. The funding agency has no role in any aspect of the trial, be this in planning or conducting the trial or in the analysis, interpretation, reporting, or dissemination of study results.

\section{Authors' Contributions}

PK was responsible for developing the search terms and conducting the database search. PK served as a screener for the title or abstract and full texts, developed the methodological approach for the search and the critical appraisal, conducted the critical appraisal, synthesized the studies' results, and prepared and drafted the manuscript. LF was responsible for developing the search terms and conducting the database search. LF served as a screener for the title or abstract and full texts, developed the methodological approach for the search and the critical appraisal, conducted the critical appraisal, and critically revised the manuscript first draft. JT critically revised the manuscript and synthesized the critical appraisal results. KW developed the methodological approach, critically revised the manuscript, and helped to develop tables of this paper. RM critically revised the manuscript and supervised the methodological approach. MS critically revised the manuscript and edited the manuscript as a native speaker. AM and SVR critically revised the manuscript.

\section{Conflicts of Interest}

None declared. 


\section{Multimedia Appendix 1}

Search terms and search characteristics.

[DOCX File, 19 KB-Multimedia Appendix 1]

\section{Multimedia Appendix 2}

Methodological quality of qualitative and mixed methods studies.

[DOC File, 94 KB-Multimedia Appendix 2]

\section{Multimedia Appendix 3}

Methodological quality of quantitative studies.

[DOC File, 149 KB-Multimedia Appendix 3]

\section{References}

1. Covell DG, Uman GC, Manning PR. Information needs in office practice: are they being met? Ann Intern Med 1985 Oct;103(4):596-599. [doi: 10.7326/0003-4819-103-4-596] [Medline: 4037559]

2. Gorman PN. Information needs of physicians. J Am Soc Inf Sci 1995 Dec;46(10):729-736. [doi: 10.1002/(sici)1097-4571(199512)46:10<729::aid-asi3>3.0.co;2-2]

3. Verhoeven A, Boerma E, Meyboom-de BJ. Use of information sources by family physicians: a literature survey. Bull Med Libr Assoc 1995 Jan;83(1):85-90 [FREE Full text] [Medline: 7703946]

4. Smith R. What clinical information do doctors need? Br Med J 1996 Oct 26;313(7064):1062-1068 [FREE Full text] [doi: 10.1136/bmj.313.7064.1062] [Medline: $\underline{8898602]}$

5. Westberg EE, Miller RA. The basis for using the Internet to support the information needs of primary care. $\mathrm{J}$ Am Med Inform Assoc 1999;6(1):6-25 [FREE Full text] [doi: 10.1136/jamia.1999.0060006] [Medline: 9925225$]$

6. Dorsch J. Information needs of rural health professionals: a review of the literature. Bull Med Libr Assoc 2000 Oct;88(4):346-354 [FREE Full text] [Medline: 11055302]

7. Dawes M, Sampson U. Knowledge management in clinical practice: a systematic review of information seeking behavior in physicians. Int J Med Inform 2003 Aug;71(1):9-15. [doi: 10.1016/s1386-5056(03)00023-6] [Medline: 12909153]

8. Coumou H, Meijman F. How do primary care physicians seek answers to clinical questions? A literature review. J Med Libr Assoc 2006 Jan;94(1):55-60 [FREE Full text] [Medline: 16404470]

9. Davies K, Harrison J. The information-seeking behaviour of doctors: a review of the evidence. Health Info Libr J 2007 Jun;24(2):78-94 [FREE Full text] [doi: 10.1111/j.1471-1842.2007.00713.x] [Medline: 17584211]

10. Younger P. Internet-based information-seeking behaviour amongst doctors and nurses: a short review of the literature. Health Info Libr J 2010 Mar;27(1):2-10 [FREE Full text] [doi: 10.1111/j.1471-1842.2010.00883.x] [Medline: 20402799]

11. Clarke MA, Belden JL, Koopman RJ, Steege LM, Moore JL, Canfield SM, et al. Information needs and information-seeking behaviour analysis of primary care physicians and nurses: a literature review. Health Info Libr J 2013 Sep;30(3):178-190 [FREE Full text] [doi: 10.1111/hir.12036] [Medline: 23981019]

12. Del Fiol G, Workman TE, Gorman PN. Clinical questions raised by clinicians at the point of care: a systematic review. JAMA Intern Med 2014 May;174(5):710-718. [doi: 10.1001/jamainternmed.2014.368] [Medline: 24663331]

13. Masters K. For what purpose and reasons do doctors use the Internet: a systematic review. Int J Med Inform 2008 Jan;77(1):4-16. [doi: 10.1016/j.ijmedinf.2006.10.002] [Medline: 17137833]

14. Wald HS, Dube CE, Anthony DC. Untangling the Web - the impact of Internet use on health care and the physician-patient relationship. Patient Educ Couns 2007 Nov;68(3):218-224. [doi: 10.1016/j.pec.2007.05.016] [Medline: 17920226]

15. Marstedt G. Das Internet: Auch Ihr Ratgeber für Gesundheitsfragen? Bevölkerungsumfrage zur Suche von Gesundheitsinformationen im Internet und zur Reaktion der Ärzte. bertelsmann-stiftung.de. Gütersloh, Germany: Bertelsmann Stiftung; 2017. URL: https://www.bertelsmann-stiftung.de/fileadmin/files/BSt/Publikationen/GrauePublikationen/ VV Studie Das-Internet-auch-Ihr-Ratgeber Befragung.pdf [accessed 2020-12-14]

16. Dutton W, Blank G, Groselj D. Cultures of the Internet: The Internet in Britain Oxford Internet Survey 2013 Report. Oxford Internet Surveys. Oxford, United Kingdom: University of Oxford; 2013. URL: http://oxis.oii.ox.ac.uk/wp-content/uploads/ 2014/11/OxIS-2013.pdf [accessed 2020-12-14]

17. Tan SS, Goonawardene N. Internet health information seeking and the patient-physician relationship: a systematic review. J Med Internet Res 2017 Jan 19;19(1):e9 [FREE Full text] [doi: 10.2196/jmir.5729] [Medline: 28104579]

18. Powell J, Inglis N, Ronnie J, Large S. The characteristics and motivations of online health information seekers: cross-sectional survey and qualitative interview study. J Med Internet Res 2011 Feb 23;13(1):e20 [FREE Full text] [doi: 10.2196/jmir.1600] [Medline: 21345783]

19. Metzger MJ, Rieh SY, Hilligoss B, Flanagin AJ, Eastin MS. Credibility of health information and digital media: new perspectives and implications for youth. In: Digital Media, Youth, and Credibility. Cambridge, London: MIT Press; 2008:123-154. 
20. Braun L, Wiesman F, van den Herik HJ, Hasman A. Avoiding literature overload in the medical domain. Stud Health Technol Inform 2006;124:497-502. [Medline: 17108567]

21. Davies K. Information needs and barriers to accessing electronic information: hospital-based physicians compared to primary care physicians. J Hosp Librariansh 2011 Jul;11(3):249-260. [doi: 10.1080/15323269.2011.587103]

22. Individuals using the Internet (\% of population). World Bank Group. 2020. URL: https://data.worldbank.org/indicator/IT. NET.USER.ZS [accessed 2020-12-14]

23. Better Systematic Review Management. Covidence. URL: https://www.covidence.org/home [accessed 2020-12-14]

24. Schmidt B, Durao S, Toews I, Bavuma C, Hohlfeld A, Nury E, et al. Screening strategies for hypertension. Cochrane Database Syst Rev 2020 May 7;5:CD013212. [doi: 10.1002/14651858.CD013212.pub2] [Medline: $\underline{32378196]}$

25. Williams A, Bird M, Hardcastle S, Kirschbaum M, Ogden K, Walters J. Exercise for reducing falls in people living with and beyond cancer. Cochrane Database Syst Rev 2018 Oct 15;10:CD011687 [FREE Full text] [doi:

10.1002/14651858.CD011687.pub2] [Medline: 30320433]

26. Casp Checklist: 10 Questions to Help You Make Sense of a Systematic Review. Critical Appraisal Skills Programme. 2018. URL: https://casp-uk.net/wp-content/uploads/2018/03/CASP-Systematic-Review-Checklist-2018 fillable-form.pdf [accessed 2020-06-30]

27. Downes MJ, Brennan ML, Williams HC, Dean RS. Development of a critical appraisal tool to assess the quality of cross-sectional studies (AXIS). BMJ Open 2016 Dec 8;6(12):e011458 [FREE Full text] [doi: 10.1136/bmjopen-2016-011458] [Medline: 27932337]

28. Guyatt G, Sackett D, Cook D. Users' guides to the medical literature. II. How to use an article about therapy or prevention. B. what were the results and will they help me in caring for my patients? Evidence-based medicine working group. J Am Med Assoc 1994 Jan 5;271(1):59-63. [doi: 10.1001/jama.271.1.59] [Medline: 8258890]

29. Wakida EK, Talib ZM, Akena D, Okello ES, Kinengyere A, Mindra A, et al. Barriers and facilitators to the integration of mental health services into primary health care: a systematic review. Syst Rev 2018 Nov 28;7(1):211 [FREE Full text] [doi: 10.1186/s13643-018-0882-7] [Medline: 30486900]

30. de Cock C, van Velthoven M, Milne-Ives M, Mooney M, Meinert E. Use of apps to promote childhood vaccination: systematic review. JMIR Mhealth Uhealth 2020 May 18;8(5):e17371 [FREE Full text] [doi: 10.2196/17371] [Medline: $\underline{32421684]}$

31. Badran H, Pluye P, Grad R. Advantages and disadvantages of educational email alerts for family physicians: viewpoint. J Med Internet Res 2015 Feb 27;17(2):e49 [FREE Full text] [doi: 10.2196/jmir.3773] [Medline: 25803184]

32. Barrett JR, Strayer SM, Schubart JR. Assessing medical residents' usage and perceived needs for personal digital assistants. Int J Med Inform 2004 Feb;73(1):25-34. [doi: 10.1016/j.ijmedinf.2003.12.005] [Medline: 15036076]

33. Boissin F. Information-seeking behaviour and use of the Internet by French general practitioners: a qualitative study. Health Info Libr J 2005 Sep;22(3):173-181 [FREE Full text] [doi: 10.1111/j.1471-1842.2005.00573.x] [Medline: 16109145]

34. Bryant S. The information needs and information seeking behaviour of family doctors. Health Info Libr J 2004 Jun;21(2):84-93 [FREE Full text] [doi: 10.1111/j.1471-1842.2004.00490.x] [Medline: 15191599]

35. Cook DA, Sorensen KJ, Wilkinson JM, Berger RA. Barriers and decisions when answering clinical questions at the point of care: a grounded theory study. JAMA Intern Med 2013 Nov 25;173(21):1962-1969. [doi:

10.1001/jamainternmed.2013.10103] [Medline: 23979118]

36. Cullen R. In search of evidence: family practitioners' use of the Internet for clinical information. J Med Libr Assoc 2002 Oct;90(4):370-379 [FREE Full text] [Medline: 12398243]

37. Ely J, Osheroff J, Gorman P, Ebell M, Chambliss M, Pifer E, et al. A taxonomy of generic clinical questions: classification study. Br Med J 2000 Aug 12;321(7258):429-432 [FREE Full text] [doi: 10.1136/bmj.321.7258.429] [Medline: 10938054]

38. Ely J, Osheroff J, Ebell M, Chambliss M, Vinson D, Stevermer J, et al. Obstacles to answering doctors' questions about patient care with evidence: qualitative study. Br Med J 2002 Mar 23;324(7339):710 [FREE Full text] [doi: 10.1136/bmj.324.7339.710] [Medline: 11909789 ]

39. Feightner J, Marshall J, Sangster L, Wathen C, Quintana Y. Evidence-based preventive practice guidelines. Qualitative study of useful resources on the Internet. Can Fam Physician 2001 Aug;47:1577-1583 [FREE Full text] [Medline: 11561334]

40. González-González AI, Dawes M, Sánchez-Mateos J, Riesgo-Fuertes R, Escortell-Mayor E, Sanz-Cuesta T, et al. Information needs and information-seeking behavior of primary care physicians. Ann Fam Med 2007;5(4):345-352 [FREE Full text] [doi: 10.1370/afm.681] [Medline: 17664501]

41. Heintze C, Matysiak-Klose D, Braun V. Perception of continuous medical education by primary care physicians. Z Arztl Fortbild Qualitatssich 2005;99(7):437-442. [Medline: 16277059]

42. Janes R, Arroll B, Buetow S, Coster G, McCormick R, Hague I. Rural New Zealand health professionals' perceived barriers to greater use of the internet for learning. Rural Remote Health 2005;5(4):436 [FREE Full text] [Medline: 16336054]

43. Lottridge DM, Chignell M, Danicic-Mizdrak R, Pavlovic NJ, Kushniruk A, Straus SE. Group differences in physician responses to handheld presentation of clinical evidence: a verbal protocol analysis. BMC Med Inform Decis Mak 2007 Jul 26;7:22 [FREE Full text] [doi: 10.1186/1472-6947-7-22] [Medline: 17655759] 
44. Schuers M, Griffon N, Kerdelhue G, Foubert Q, Mercier A, Darmoni SJ. Behavior and attitudes of residents and general practitioners in searching for health information: from intention to practice. Int J Med Inform 2016 May;89:9-14. [doi: 10.1016/j.ijmedinf.2016.02.003] [Medline: 26980354]

45. Vaucher C, Bovet E, Bengough T, Pidoux V, Grossen M, Panese F, et al. Meeting physicians' needs: a bottom-up approach for improving the implementation of medical knowledge into practice. Health Res Policy Syst 2016 Jul 18;14(1):49 [FREE Full text] [doi: 10.1186/s12961-016-0120-5] [Medline: 27431911]

46. Zack P, Devile C, Clark C, Surtees R. Understanding the information needs of general practitioners managing a rare genetic disorder (osteogenesis imperfecta). Community Genet 2006;9(4):260-267. [doi: 10.1159/000094475] [Medline: 17003536]

47. Andrews J, Pearce K, Ireson C, Love M. Information-seeking behaviors of practitioners in a primary care practice-based research network (PBRN). J Med Libr Assoc 2005 Apr;93(2):206-212 [FREE Full text] [Medline: 15858623]

48. Bennett NL, Casebeer LL, Kristofco R, Collins BC. Family physicians' information seeking behaviors: a survey comparison with other specialties. BMC Med Inform Decis Mak 2005 Mar 22;5:9 [FREE Full text] [doi: 10.1186/1472-6947-5-9] [Medline: 15784135$]$

49. Bernard E, Arnould M, Saint-Lary O, Duhot D, Hebbrecht G. Internet use for information seeking in clinical practice: a cross-sectional survey among French general practitioners. Int J Med Inform 2012 Jul;81(7):493-499. [doi: 10.1016/j.ijmedinf.2012.02.001] [Medline: 22425281]

50. Bjerre LM, Paterson NR, McGowan J, Hogg W, Campbell CM, Viner G, et al. What do primary care practitioners want to know? A content analysis of questions asked at the point of care. J Contin Educ Health Prof 2013;33(4):224-234. [doi: 10.1002/chp.21191] [Medline: 24347101]

51. Butzlaff M, Koneczny N, Floer B, Vollmar H, Lange S, Kunstmann W, et al. Family physicians, the internet and new knowledge. Utilization and judgment of efficiency of continuing education media by general physicians and internists in family practice. Med Klin (Munich) 2002 Jul 15;97(7):383-388. [doi: 10.1007/s00063-002-1170-8] [Medline: 12168475]

52. Ciarlo G, Liebl P, Zell J, Fessler J, Koester M, Ruetters D, et al. Information needs of oncologists, general practitioners and other professionals caring for patients with cancer. Eur J Cancer Care (Engl) 2016 Nov;25(6):1015-1023. [doi: 10.1111/ecc.12557] [Medline: 27550233]

53. Cogdill KW, Friedman CP, Jenkins CG, Mays BE, Sharp MC. Information needs and information seeking in community medical education. Acad Med 2000 May;75(5):484-486. [doi: 10.1097/00001888-200005000-00020] [Medline: 10824774]

54. Denny B, Chester A, Butler M, Brown J. Australian GP registrars' use of e-resources. Educ Prim Care 2015 Mar;26(2):79-86. [doi: 10.1080/14739879.2015.11494317] [Medline: 25898296]

55. Dwairy M, Dowell AC, Stahl J. The application of foraging theory to the information searching behaviour of general practitioners. BMC Fam Pract 2011 Aug 23;12:90 [FREE Full text] [doi: 10.1186/1471-2296-12-90] [Medline: 21861880]

56. Ebell MH, Cervero R, Joaquin E. Questions asked by physicians as the basis for continuing education needs assessment. J Contin Educ Health Prof 2011;31(1):3-14. [doi: 10.1002/chp.20095] [Medline: 21425354]

57. Koller M, Grütter R, Peltenburg M, Fischer J, Steurer J. Use of the Internet by medical doctors in Switzerland. Swiss Med Wkly 2001 May 5;131(17-18):251-254. [Medline: 11420822]

58. Kortekaas MF, Bartelink ME, Boelman L, Hoes AW, de Wit NJ. General practice trainees' information searching strategies for clinical queries encountered in daily practice. Fam Pract 2015 Oct;32(5):533-537. [doi: 10.1093/fampra/cmv046] [Medline: 26089299]

59. Kostagiolas P, Martzoukou K, Kakavitsas F, Niakas D. The participatory medicine attitudes of general practitioners in greece: an information behaviour perspective. In: Kurbanoglu S, Boustany J, Spiranec S, editors. Information Literacy: Moving Toward Sustainability. Switzerland: Springer International Publishing; 2015:383-393.

60. Kosteniuk JG, Morgan DG, D'Arcy CK. Use and perceptions of information among family physicians: sources considered accessible, relevant, and reliable. J Med Libr Assoc 2013 Jan;101(1):32-37 [FREE Full text] [doi: 10.3163/1536-5050.101.1.006] [Medline: 23405045]

61. Kritz M, Gschwandtner M, Stefanov V, Hanbury A, Samwald M. Utilization and perceived problems of online medical resources and search tools among different groups of European physicians. J Med Internet Res 2013 Jun 26;15(6):e122 [FREE Full text] [doi: 10.2196/jmir.2436] [Medline: 23803299]

62. Le JV, Pedersen LB, Riisgaard H, Lykkegaard J, Nexøe J, Lemmergaard J, et al. Variation in general practitioners' information-seeking behaviour - a cross-sectional study on the influence of gender, age and practice form. Scand J Prim Health Care 2016 Dec;34(4):327-335 [FREE Full text] [doi: 10.1080/02813432.2016.1249057] [Medline: 27804315]

63. MacWalter G, McKay J, Bowie P. Utilisation of internet resources for continuing professional development: a cross-sectional survey of general practitioners in Scotland. BMC Med Educ 2016 Jan 21;16:24 [FREE Full text] [doi: 10.1186/s12909-016-0540-5] [Medline: 26791566]

64. Magin P, Morgan S, Wearne S, Tapley A, Henderson K, Oldmeadow C, et al. GP trainees' in-consultation information-seeking: associations with human, paper and electronic sources. Fam Pract 2015 Oct;32(5):525-532. [doi: 10.1093/fampra/cmv047] [Medline: 26089297]

65. Magin P, Tapley A, Davey A, Morgan S, Holliday E, Ball J, et al. General practitioner trainees' in-consultation generation of clinical questions for later answering: prevalence and associations. Fam Pract 2017 Sep 1;34(5):599-605. [doi: 10.1093/fampra/cmx021] [Medline: 28369454] 
66. Magrabi F, Westbrook JI, Kidd MR, Day RO, Coiera E. Long-term patterns of online evidence retrieval use in general practice: a 12-month study. J Med Internet Res 2008 Mar 19;10(1):e6 [FREE Full text] [doi: 10.2196/jmir.974] [Medline: $\underline{18353750]}$

67. Ruf D, Berner M, Kriston L, Maier I, Härter M. General practitioners online: the conditions are good, but use of the Internet for continuing medical education found to be poor. Z Evid Fortbild Qual Gesundhwes 2008;102(5):291-297. [doi: 10.1016/j.zefq.2008.02.023] [Medline: 19006916]

68. Schwartz K, Northrup J, Israel N, Crowell K, Lauder N, Neale A. Use of on-line evidence-based resources at the point of care. Fam Med 2003 Apr;35(4):251-256. [Medline: 12729308]

69. Vollmar H, Ostermann T, Hinz A, Rieger M, Butzlaff M. Primary care physicians, internet and educational media. Preferences, usages and appraisal in a 6-year comparison. Med Klin (Munich) 2008 Jun 15;103(6):425-432. [doi: 10.1007/s00063-008-1055-6] [Medline: 18548212]

70. Vollmar HC, Rieger MA, Butzlaff ME, Ostermann T. General Practitioners' preferences and use of educational media: a German perspective. BMC Health Serv Res 2009 Feb 16;9:31 [FREE Full text] [doi: 10.1186/1472-6963-9-31] [Medline: 19220905]

71. Thomas J, Harden A. Methods for the thematic synthesis of qualitative research in systematic reviews. BMC Med Res Methodol 2008 Jul 10;8:45 [FREE Full text] [doi: 10.1186/1471-2288-8-45] [Medline: 18616818]

72. Möhler R, Meyer G. Attitudes of nurses towards the use of physical restraints in geriatric care: a systematic review of qualitative and quantitative studies. Int J Nurs Stud 2014 Feb;51(2):274-288. [doi: 10.1016/j.ijnurstu.2013.10.004] [Medline: 24176718]

73. Mayring P. Qualitative Content Analysis: Theoretical Foundation, Basic Procedures and Software Solution. Social Science Open Access Repository. 2014. URL: http://nbn-resolving.de/urn:nbn:de:0168-ssoar-395173 [accessed 2020-12-14]

74. Hong QN, Pluye P, Bujold M, Wassef M. Convergent and sequential synthesis designs: implications for conducting and reporting systematic reviews of qualitative and quantitative evidence. Syst Rev 2017 Mar 23;6(1):61 [FREE Full text] [doi: 10.1186/s13643-017-0454-2] [Medline: 28335799]

75. Carston R. The explicit/implicit distinction in pragmatics and the limits of explicit communication. Int Rev Pragmat 2009;1(1):35-62. [doi: 10.1163/187731009x455839]

76. Moher D, Liberati A, Tetzlaff J, Altman DG, PRISMA Group. Preferred reporting items for systematic reviews and meta-analyses: the PRISMA statement. Br Med J 2009 Jul 21;339:b2535 [FREE Full text] [doi: 10.1136/bmj.b2535] [Medline: 19622551]

77. Simons MR, Zurynski Y, Cullis J, Morgan MK, Davidson AS. Does evidence-based medicine training improve doctors' knowledge, practice and patient outcomes? A systematic review of the evidence. Med Teach 2019 May;41(5):532-538. [doi: 10.1080/0142159X.2018.1503646] [Medline: 30328793]

78. Sackett DL, Rosenberg WM, Gray JA, Haynes RB, Richardson WS. Evidence based medicine: what it is and what it isn't. Br Med J 1996 Jan 13;312(7023):71-72 [FREE Full text] [doi: 10.1136/bmj.312.7023.71] [Medline: $\underline{\text { 8555924] }}$

79. Dixon-Woods M, Agarwal S, Jones D, Young B, Sutton A. Synthesising qualitative and quantitative evidence: a review of possible methods. J Health Serv Res Policy 2005 Jan;10(1):45-53. [doi: 10.1177/135581960501000110] [Medline: 15667704]

\author{
Abbreviations \\ AXIS: appraisal tool for cross-sectional studies \\ CASP: critical appraisal skills program \\ CME: continuous medical education \\ EBM: evidence-based medicine \\ FP: family physician \\ GP: general physician \\ MeSH: Medical Subject Headings
}

Edited by G Eysenbach; submitted 20.03.20; peer-reviewed by $R$ Koch, C SteeleGray, J Li; comments to author 22.06.20; revised
version received 20.07.20; accepted 11.11.20; published 30.12.20
Please cite as:
van der Keylen P, Tomandl J, Wollmann K, Möhler R, Sofroniou M, Maun A, Voigt-Radloff S, Frank L
The Online Health Information Needs of Family Physicians: Systematic Review of Qualitative and Quantitative Studies
J Med Internet Res 2020;22(12):e18816
URL: $\underline{\text { http://www.jmir.org/2020/12/e18816/ }}$
doi: $\underline{10.2196 / 18816}$
PMID: $\underline{3377874}$ 
CPiet van der Keylen, Johanna Tomandl, Katharina Wollmann, Ralph Möhler, Mario Sofroniou, Andy Maun, Sebastian Voigt-Radloff, Luca Frank. Originally published in the Journal of Medical Internet Research (http://www.jmir.org), 30.12.2020. This is an open-access article distributed under the terms of the Creative Commons Attribution License (https://creativecommons.org/licenses/by/4.0/), which permits unrestricted use, distribution, and reproduction in any medium, provided the original work, first published in the Journal of Medical Internet Research, is properly cited. The complete bibliographic information, a link to the original publication on http://www.jmir.org/, as well as this copyright and license information must be included. 